\title{
A basic radial dike swarm of Boa Vista (Cape Verde Archipelago); its significance in the evolution of the island
}

\author{
Eumenio Ancochea ${ }^{a, *}$, Francisco Hernán ${ }^{b}$, María José Huertas ${ }^{a}$, José Luis Brändle ${ }^{c}$ \\ a Dpto. Petrologín y Geoquímica, Fac. Ciencias Geológicas, Universidad Complutense, 28040 Madrid, Spain \\ b Dpto. Edafologia y Geologia, Universidad de La Lanua, 38206 La Laguna, Tenerife, Spain \\ ' Inst. Geología Económic (CSIC, Universidad Complutense), 28040 Madrid, Spain
}

\section{Keywords:}

Basic dikes

Radial dikes

Oceanic islands

Boa Vista Island

Cape Verde Islands

\begin{abstract}
A B S T R A C T
A basic radial dike swarm unrelated to other basic units of Boa Vista (Cape Verde Archipelago) has been localized and characterized in the central sector of the island.

According to new radiometric data three main stages in the evolution of Boa Vista are distinguished: the earlier (the Old Volcanic Complex: 17-16 Ma) is equivalent to the shield building stage of Hawaii and the later (the Recent Volcanics ( $8-4 \mathrm{Ma}$ ) is in some aspects comparable to the post-erosional stage. An important intermediate essentially felsic stage (the Trachytic-Phonolitic Complex: 14.3-12.8 Ma) followed the basaltic shield stage. This felsic stage has equivalents in some other oceanic islands as the Canary Islands, specially Gran Canaria, Tenerife, and La Gomera. The central sector of Boa Vista is also occupied by the Felsic Subvolcanic Complex, a unit consisting of phonolitic breccias, syenites and monzonites that represent the Trachytic-Phonolitic Complex hypabyssal roots. The felsic rocks as a whole constitute half of the total amount of igneous rocks on the island making up Boa Vista, the island with the highest percentage of felsic rocks in the Central Atlantic Ocean.

More than 200 dikes of the basic radial swarm intruding the Felsic Subvolcanic Complex have been measured. The intensity of the multiple dike injection is sometimes rather high, roughly a dike every $5 \mathrm{~m}$. The individual dikes have an observable mean length of about $300 \mathrm{~m}$. The composition of these dikes is always foiditic (nephelinites, melilitites, and limburgites), slightly different in composition (more alkaline and richer in incompatible elements) to the other basic units of the island (the Old Volcanic Complex and the Recent Volcanics). The radial dikes converge in an area located NW of the geometrical center of Boa Vista, a zone where the hypothetical center of the Old Volcanic Complex and the Trachytic-Phonolitic Complex edifices must also have been situated. The ages obtained from the dikes (between 14.8 and $11.5 \mathrm{Ma}$ ) indicate that the radial injections are contemporary with the phonolites and the trachytes of the Trachytic-Phonolitic Complex and yet are part of the intermediate evolutionary stage of Boa Vista.
\end{abstract}

\section{Introduction}

Dike swarms accompanying volcanic edifices not only provide information about magma generation and ascent, but they also reflect the regional and local stresses existent in every particular stage of their development (i.e. Richey, 1939; Anderson, 1951). This information is especially important when dealing with volcanic complexes of long lasting evolution in which, the successive and overlapping constructive and erosive stages that occurred hinder their global understanding. This is the case with oceanic islands as those of the Cape Verde and the Canary Archipelagos that are located on a more or less stationary plate (i.e. Pollitz, 1991) and yet have been active throughout several million years.
Thus, the study of dike swarms has been key in the understanding of the volcanic history of some of the Canary Islands (i.e.: Schmincke, 1967; Hernán, 1976; Feraud et al., 1985; Stillman, 1987; Schirnick, et al., 1999; Marinoni and Gudmunsson, 2000; Walter and Schmincke, 2002). The results have been rather satisfactory in the reconstruction of the early stage of growth (the old edifices) in the island of La Palma (Staudigel et al., 1986; Ancochea et al., 1994), in Tenerife (Ancochea et al., 1990, 1999), or in Fuerteventura. (Coello et al., 1992; Ancochea et al., 1996; Ancochea and Huertas, 2003). In La Gomera, an island that show some similarities with Boa Vista, it is important to emphasize the existence of different felsic dike swarms (Ancochea et al., 2003) and basaltic radial dike swarms (Ancochea et al., 2008) the location of which has been migrating with time.

The systematic study of Cape Verde dike swarms was initiated in Sao Vicente, an island where several basaltic radial dike swarms were also identified. The dike arrangement allowed us to reconstruct the original geometry of the old volcanic edifice and also to find the 
trace left by a giant slide that destroyed its eastern flank (Huertas et al., 2006; Ancochea et al., 2010; Hernán et al., 2011).

The island of Boa Vista has also had prolonged volcanic activity during at least 12 million years (Dyhr and Holm, 2010) and it is so deeply eroded that the hypabyssal roots are exhibited. The aim of this work is the study of the basic dikes which, have not been taken into account by previous authors but are key to the interpretation of the volcanic history of Boa Vista. We analyze here their geometric and temporal characteristics in order to relate them to the subaerial magmatic episodes and so, on the basis of the new field, age, and geochemical data, a volcano-stratigraphic and evolutionary model is proposed for the island.

\section{Boa Vista island}

The Cape Verde islands are located west of the Senegal coast, between $14^{\circ}$ and $17^{\circ}$ North latitude and between $22^{\circ}$ and $26^{\circ}$ West longitude (Fig. 1). The archipelago is formed by ten major islands that are distributed along two different alignments intersected in a horseshoe shape: the leeward alignment (Sotavento islands, to the South) and the windward alignment (Barlovento islands, to the North). Boa Vista which, is located in the intersection of the two alignments, is the easternmost island of the archipelago and third in size, with $620 \mathrm{~km}^{2}$ of extension.

Boa Vista is in geologic terms one of the less known Cape Verde islands. Bebiano (1932) described for the first time the lithologic types existent on the island and advanced a schematic cartography. Many years later Serralheiro et al. (1974) published a fundamental work on the geology of the island that is based on detailed geologic mapping summarized on a 1:100,000 scale. A few notes are later published on different specific geological aspects of Boa Vista (i.e. Figueiredo et al., 1989 or Silva et al., 1989) as well as the petrology and geochemistry of the main units (Macedo et al., 1995). Recently, Dyhr and Holm (2010) have provided the first radiometric dating of the island which, with some pauses, has been active from $16 \mathrm{Ma}$ to $4 \mathrm{Ma}$. In addition, these authors display a stratigraphic scheme and an ample and detailed geochemical and petrogenetic study.
All the eastern Cape Verde islands have been intensely eroded; the highest reliefs reach only about 400 masl (387 m on Boa Vista, $406 \mathrm{~m}$ on Sal and $436 \mathrm{~m}$ on Maio). Particularly in Boa Vista only six points exceed $300 \mathrm{~m}$ in height. Neither Maio nor Boa Vista have experienced recent volcanic activity capable to rejuvenate the island.

The scarce volcanic activity that occurred throughout the last million years together with the intense marine abrasion are the main factors marking the present flat relief of Boa Vista; the island is characterized by less than $100 \mathrm{~m}$ high extensive plains (Fig. 2) frequently capped by dunes, volcanoclastic deposits and calcareous sediments. The main heights appear either as small isolated hills in the south-west or as part of a long and $200 \mathrm{~m}-300 \mathrm{~m}$ high arched band that extends from SE to $\mathrm{N}$ sub-parallel to the coast (Fig. 2a). The ample flat areas usually correspond to marine terraces implying that, to a certain extent, the island was covered by sea waters (Ramalho et al., 2010).

\section{Volcanostratigraphy and growth stages of Boa Vista}

Three main growth stages can be distinguished in the volcanologic history of Boa Vista: the Old Volcanic Complex, the TrachyticPhonolitic Complex and the Recent Volcanics, which are roughly equivalent to the activity stages 1, 2 and 3 of Dyhr and Holm (2010).

The Old Volcanic Complex (OVC, Table 1 and Fig. 3), the oldestvolcanic unit, was formed by intensely eroded and weathered basaltic lava flows which, occasionally show a submarine character and sometimes are crossed by dikes. It is exposed mainly in the eastern part of the island and in some other points in the south (Fig. 3). Serralheiro et al. (1974) designated the unit as "Fundo de Figueira Formation (\$1)" (Table 1 ), have estimated dips about $8^{\circ}-10^{\circ}$ and mentioned the presence of small carbonatitic inclusions in the lava flows. By comparison with other oceanic islands, this unit must represent the main growth stage of Boa Vista though at the present time does not stand out in the island relief.

The Trachytic-Phonolitic Complex (TPC, Table 1 and Fig. 3), the second major volcanic unit, is constituted of phonolites and trachytes. On the basis of stratigraphic criteria, Serralheiro et al. (1974) distinguished

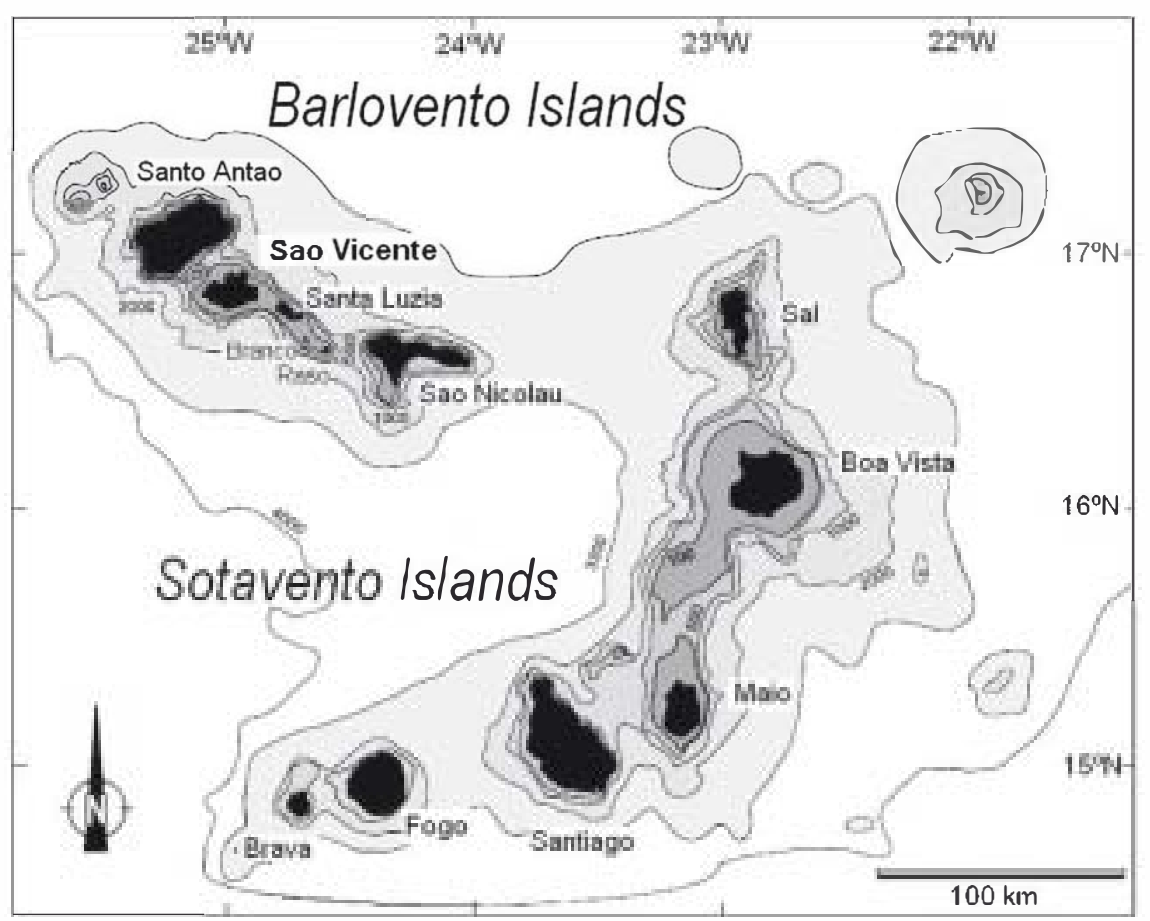

Fig. 1. Location and bathymetric map of the Cape Verde Islands (Ancochea et al., 2010). Based on Holm et al (2008). 
b)
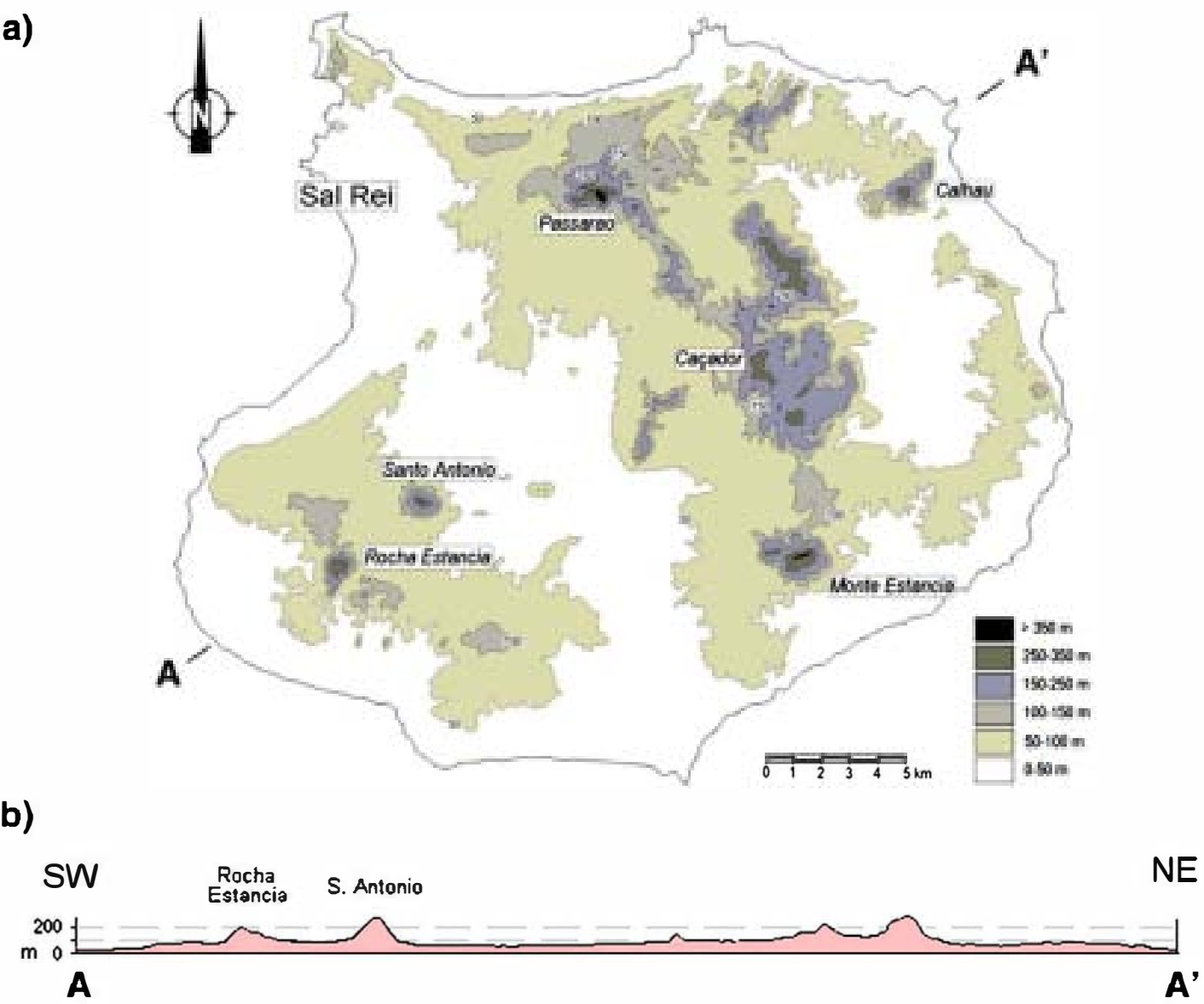

Fig. 2. a: Schematic topographic map of Boa Vista and main reliefs. b: Representative topographic profile.

three felsic units: Complexo de Monte Passarao, Monte Caçador Formation and Pico Forçado Formation (Table 1). As a whole, they are equivalent to the "Intermediate volcanic rocks" of Dyhr and Holm (2010) who also distinguished three compositional groups of rocks: group 1 of Ne-normative trachytes with low $\mathrm{Zr}$-content, group 2 of trachytes and group 3 of phonolites. Since no correspondence exists between these two subdivisions, we have included all these felsic rocks in a single volcanic unit: the TPC.

The TPC is, in stratigraphic terms, an extraordinarily complex unit composed of lava flows, breccias, tuffs, ignimbrites, domes and dikes with a compositional variety of rocks from trachytes to phonolites which occupy the highest hills in the SW and the prominent arcuate band in the $\mathrm{E}$ (Figs. 2 and 3).

Although a part of the TPC, the "Complexo de Monte Passarao ( 1 1)" (Table 1) of Serralheiro et al. (1974) (composed of trachytic and phonolitic lava flows, breccias, ignimbrites and dikes) was interpreted by these authors as older than the OVC basalts we have not found any sort of criteria to separate them from the rest of the trachytes and phonolites that are obviously younger than the OVC.

On the other hand, there are other felsic rocks in the central area of the island; some syenites, monzonites and more or less porphyritic trachytes and phonolites crossed by basic and felsic dikes crop out

Table 1

Volcano-stratigraphic models of Boa Vista Island.

\begin{tabular}{|c|c|c|c|}
\hline \multirow[t]{2}{*}{ Serralheiro et al. (1974) and Macedo et al. (1995) } & \multirow{2}{*}{$\begin{array}{l}\text { Dyhr and Holm (2010) } \\
\text { Units }\end{array}$} & \multicolumn{2}{|l|}{ This work } \\
\hline & & Volcanic units & Subvolcanic units \\
\hline $\begin{array}{l}\text { Monte Negro Formation } \\
\text { (33) }\end{array}$ & $\begin{array}{l}\text { Young volcanic rocks } \\
\text { (activity stage } 3 \text { ) }\end{array}$ & $\begin{array}{l}\text { Recent Volcanics } \\
\text { (RV) }\end{array}$ & \\
\hline $\begin{array}{l}\text { Chao da Caleta Formation } \\
\text { ( } 2 \text { 2) }\end{array}$ & 8.6 to $4.7 \mathrm{Ma}$ & 6.1 to $4.3 \mathrm{Ma}$ & \\
\hline $\begin{array}{l}\text { Pico Forçado Formation } \\
(\varphi 2)\end{array}$ & $\begin{array}{l}\text { Intermediate volcanic rocks } \\
\text { (activity stage } 2 \text { ) }\end{array}$ & $\begin{array}{l}\text { Trachytic-Phonolitic Complex } \\
\text { (TPC) }\end{array}$ & $\begin{array}{l}\text { Basic radial swarm (BRS) } \\
14.8 \text { to } 11.5 \mathrm{Ma}\end{array}$ \\
\hline Monte Caçador Formation ( $\varphi c)$ & $\begin{array}{l}\text { Group 3: } \\
13.22 \text { and } 12.8 \mathrm{Ma} \\
\text { Group 2: } \\
14.3 \text { and } 14.22 \mathrm{Ma} \\
\text { Group } 1:(? \mathrm{Ma})\end{array}$ & & $\begin{array}{l}\text { Felsic Subvolcanic Complex } \\
\text { (FSC) } \\
14.3 \text { to } 12.8 \mathrm{Ma}\end{array}$ \\
\hline Fundo de Figueira Formation ( 1 ) & $\begin{array}{l}\text { Old volcanic rocks } \\
\text { (activity stage } 1 \text { ) } \\
16.5 \mathrm{Ma}\end{array}$ & $\begin{array}{l}\text { Old Volcanic Complex (OVC) } \\
17.5 \text { and } 16.4 \mathrm{Ma}\end{array}$ & \\
\hline $\begin{array}{l}\text { Complexo de Monte Passarao ( } \varphi 1) \\
\text { Complexo eruptivo interno antigo (CA) }\end{array}$ & & & \\
\hline
\end{tabular}




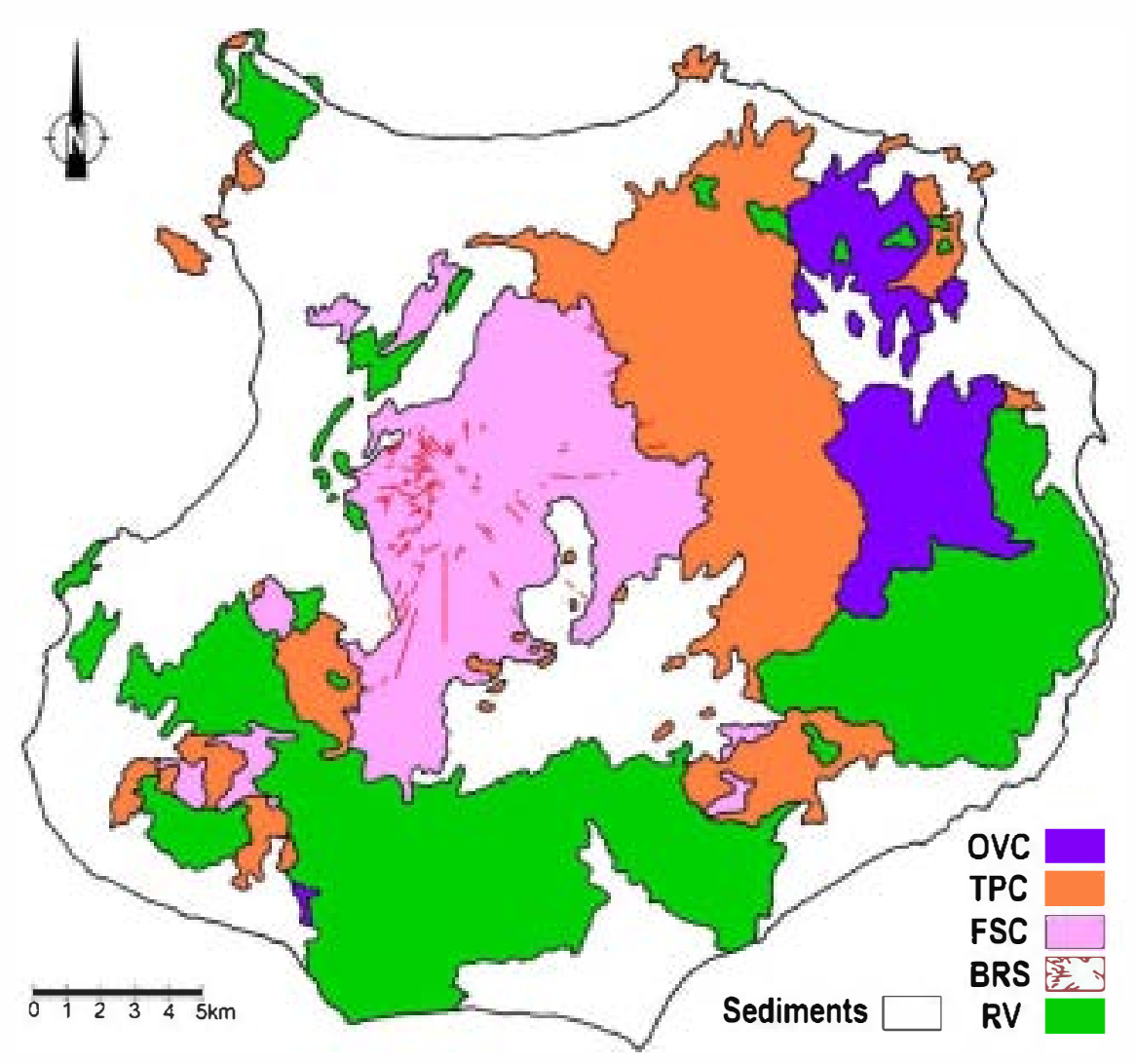

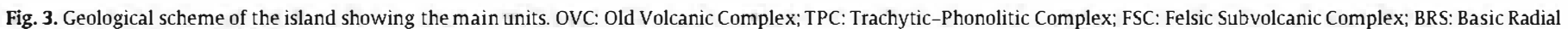
Swarm and RV: Recent Volcanics.

partially covered by recent sedimentary deposits. We consider the whole as the Felsic Subvolcanic Complex (FSC). Serralheiro et al. (1974) and Macedo et al. (1995) identified these outcrops as the "Complexo eruptivo interno antigo", a unit also existent in some other islands of the archipelago (i.e. in Santiago, Matos Alves et al., 1979) that represented an ancient basement for all the younger volcanic units.

The geological meaning of the "Complexos eruptivos internos antigos" of Cape Verde is similar to that of the "Basal Complexes" of the Canary Islands (i.e. Fúster et al., 1968; Stillman et al., 1975). Notwithstanding, as we have already stated in previous works, these units include not only the submarine growth stage of the island but also the subvolcanic roots (plutonic bodies and dikes) of both the submarine and the later subaerial volcanics (Ancochea et al., 1996).

Nevertheless, the FSC cannot be considered as the "Basal Complex" or "Complexo eruptivo interno antigo" of Boa Vista because neither marine sediments nor submarine basaltic lava flows are found within the whole and therefore it can hardly represent the submarine growth stage of Boa Vista. The characteristic intense diking of this type of "complexes" are also lacking in the FSC, and also, as we discuss further on, according to the radiometric age data this unit is not at all the oldest one. Thus, the Felsic Subvolcanic Complex rocks are the deeper hypabyssal roots of the trachytic and phonolitic activity of the Trachytic-Phonolitic Complex.

The Recent Volcanics (RV, Table 1 and Fig. 3), the most recent activity, are again basic in composition: basalts, basanites and foidites which spread out all over the island. Serralheiro et al. (1974) and Macedo et al. (1995) distinguished two different units: one older and more extensive ( 2 ) and another one hypothetically younger because of the existence of a few pyroclastic eruption centers (3) which, still stand out on the landscape. However, the radiometric data of Dyhr and Holm (2010) and also the new ones supplied in the present paper give similar ages to these hypothetical units.
According to Macedo et al. (1995), the sediments and the sedimentary rocks occupy $50 \%$ of the total island surface, $25 \%$ correspond to the basic volcanic rocks (OVC and RV), 16\% to phonolites and trachytes (TPC) and the remaining 9\% to the FSC which means that both felsic and basic magmatic rocks almost have a similar extent.

\section{The basic radial swarm (BRS)}

Most of the basic dikes are exposed crossing the FSC rocks in the central area (Fig. 3) though a few cross the TPC rocks in the NE sector. An initial approach to the location of the basic dikes set in the central core of the island and the two also basic units existent in the periphery suggests a certain relationship between the dikes and one of the units (either the OVC or the RV).

Serralheiro et al. (1974) mentioned these basic dikes for the first time but they considered them to form part of their "Complexo eruptivo interno antigo" discarding any relationships between the dikes and the basic units. Macedo et al. (1995) also mentioned the radial character of the dikes and suggested their possible relationship with the Cha de Caleta Formation ( 2 ), a part of our RV (Table 1). No data were obtained to support any of these interpretations.

Fig. 4 shows how the basic dikes, despite some local differences, follow a clear radial pattern. In the NW and $W$ sectors of the radial dike swarm, the dikes essentially cross highly hydrothermally weathered felsic breccias. Due to the very scarce sedimentary cover, the number of dikes here is abundant (up to $58 \%$ of the total amount) and they appear closely spaced (approximately one every $5 \mathrm{~m}$ ). Most are of small thickness, $1 \mathrm{~m}$ or less, highly weathered and typically excavated by erosion (Fig. 5a).

The dikes in the other sectors, much longer, somewhat thicker $(>1 \mathrm{~m}$ ), and more widely spaced (hundreds of meters), intrude syenites, felsic breccias and phonolites capped by an important amount of recent sediments. The host rock is seldom exposed, mostly 


\section{Basic Radial Swarm}

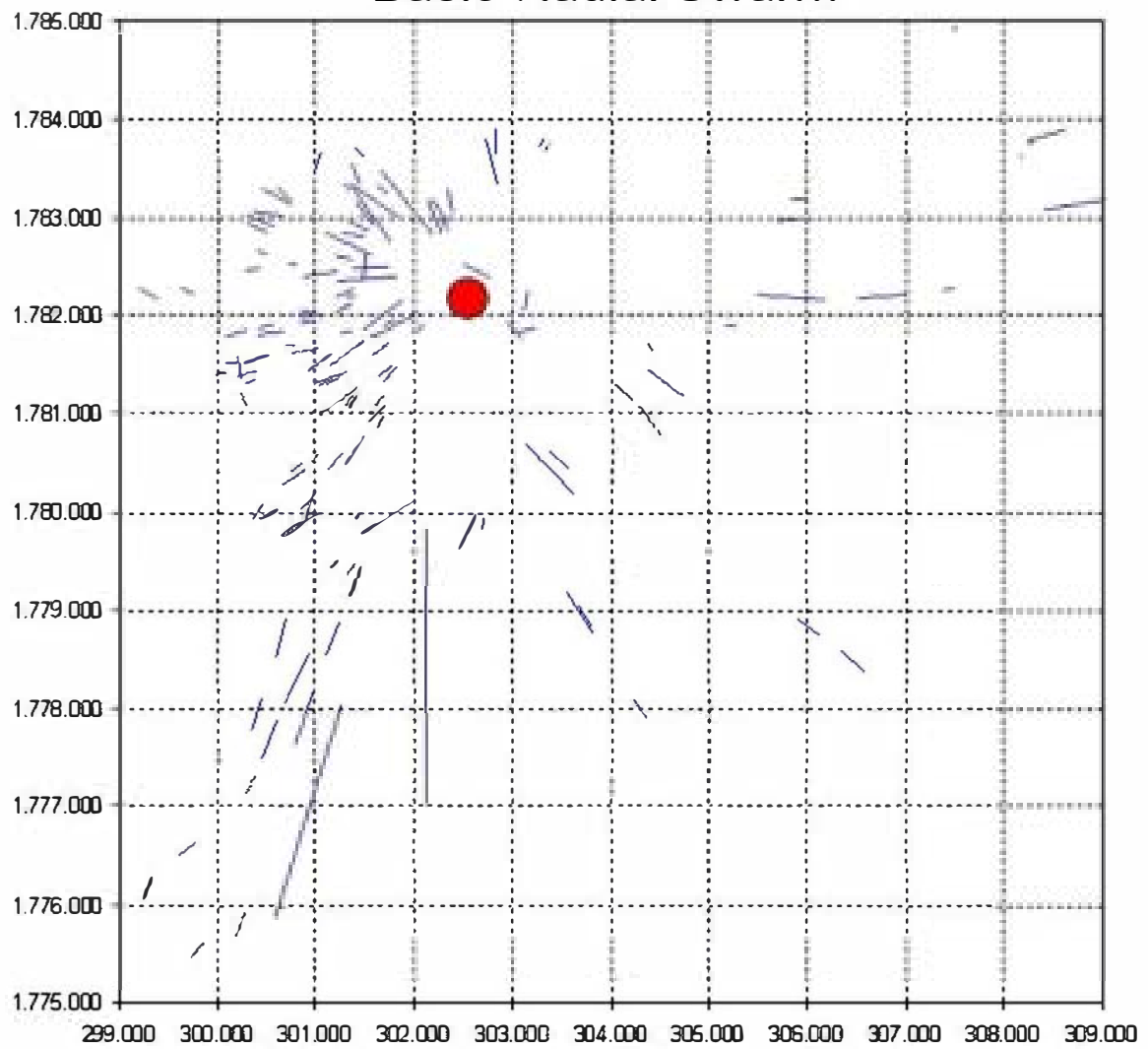

Fig. 4. Distribution of the basic dikes. Circle: estimated center. UTM coordinates.

observed along the walls of the most deeply excavated watercourses. The thickest dikes here are distinguished among the sedimentary cover standing out slightly by differential erosion (Fig. Sb), although some others are recognized only because of lineal concentrations of dark basic rock fragments.

The great length of many dikes, their dark color contrasting the clear one of the host rock or of the recent sediments, their positive or negative differential erosion relief with respect to the host rock and, lastly, the almost total lack of vegetation, have allowed us to make their identification and mapping by use of satellite images. The total amount of dikes either measured on the field or identified by satellite image is 231 dikes.

The observable length of dikes varies from at least $30 \mathrm{~m}$ to $2800 \mathrm{~m}$ long (Fig. 6). Approximately two-thirds (67\%) have a visible length of between 100 and $300 \mathrm{~m}$. As for the thickness, it ranges between 30 and $300 \mathrm{~cm}$. Most dikes (60\%) are 40-120 cm thick (Fig. 7), the average thickness being $127 \mathrm{~cm}$ and the standard deviation $73 \mathrm{~cm}$. Their dip when visible is always vertical.

As may be appreciated in Fig. 4, the distribution of dikes is obviously radial, even if the radial pattern is apparently not so clear when the dike trends are plotted on a rose diagram (Fig. 8). This is due to the different number of dikes exposed which reach their maximum where the outcrop area is more extensive, that is to say where the sedimentary cap is less extensive (between $\mathrm{N} 200^{\circ} \mathrm{E}$ and $\mathrm{N} 320^{\circ} \mathrm{E}$ ). The maximum number of dikes $(10 \%)$ coincides with $\mathrm{N} 230^{\circ} \mathrm{E}-240^{\circ} \mathrm{E}$.

In order to locate the approximate position of the radial swarm center we have used the method of maximum intersections (Brändle et al., 1991), already reported and applied in some previous papers dealing with the reconstruction of diverse old edifices on some of the Canary Islands (Ancochea et al., 2003, 2008) and Cape Verde (Ancochea et al., 2010).

The central area estimated for the dike swarm (area in which the convergence of dikes is maximum (red circle, Fig. 4) has its center located by the UTM coordinates: 302.491 and 1.782.248 (Zone 27Q), some $800 \mathrm{~m}$ west of Morro Amadeirinho (a known peak in the island). In order to discriminate different hypothetical dike families we have also considered short and long dikes separately, but no significant differences between both groups of dikes are appreciated.

\section{Composition of the basic dikes}

All dikes have a rather similar composition. Rocks appear aphanitic or microcrystalline porphyritic with visible olivine and clinopyroxene phenocrysts in hand sample. In some cases, mostly in thick dikes, the rocks are ankaramites. Some other times, biotite phenocrysts are also distinguished. The rocks are holocrystalline or hypocrystalline under the microscope, with a varied content in olivine and clinopyroxene phenocrysts surrounded by a criptocrystalline or, exceptionally, by a fine-grained or a vitreous groundmass. The groundmass is formed by augite microlites, Ti and Fe oxides, apatite microcrystals and occasional interstitial nepheline patches partially transformed into zeolite. In some cases, variable amounts of biotite, amphibole and, more exceptionally, melilite and perovskite are also observed.

The clinopyroxene is the dominant mafic mineral. It is characterized by a variety of sizes of unaltered sub-euhedral and anhedral crystals. They are markedly pink-brown in color and show common twinning and zoning. The olivine crystals are sometimes partially or totally transformed into iddingsite or, more occasionally, replaced by serpentinitic aggregates. The biotite, which is more abundant than the amphibole, is found as microphenocrysts and small sub-euhedral tabular crystals in the groundmass of many of the dikes. The amphibole is also found as microphenocrysts and is, as well as the biotite, very rarely altered.

Furnes and Stillman (1987) described in the nearby island of Maio an intense swarm of sheet intrusions of (basanitic) alkaline 
a)

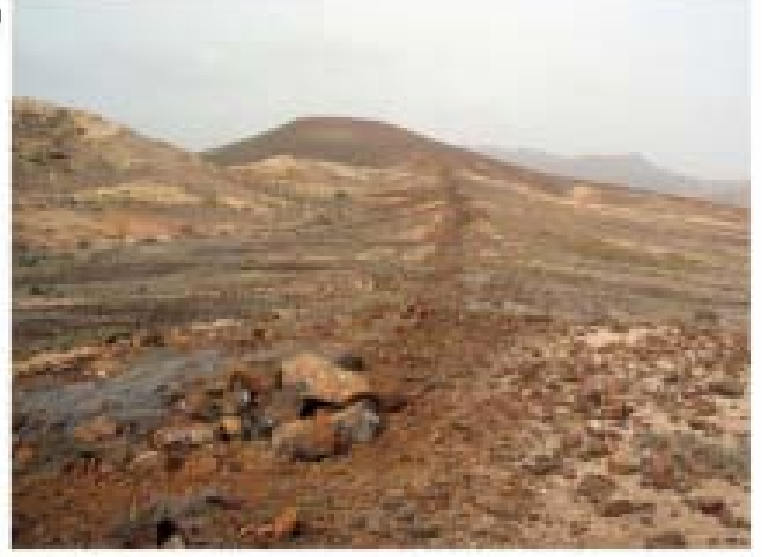

b)

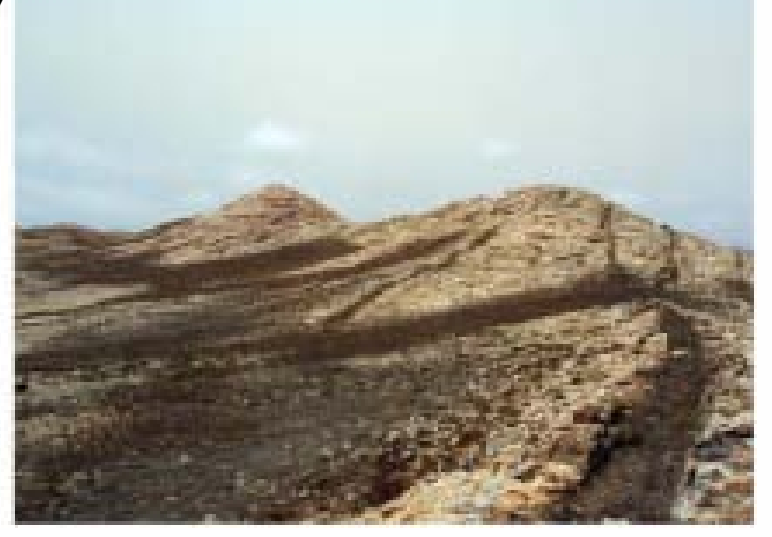

Fig. 5. a) General aspect of dikes in the NW and $W$ sector of the dike swarm: they ex hibit bas-relief with respect to the felsic brecciaed host rock. b) A representative long dike standing out from the host rock in the eastern sector of the dike swarm.

lamphrophyres, ranging in age from 16 to 8 Ma so that they are partially contemporary with the BRS dikes. Though some of the BRS dikes could be considered as alkali lamphrophyres: firstly a great part of them are aphanitic, and secondly biotite and amphibole are only eventually found and never as essential minerals. These facts hinder the use of this term for these rocks (Le Maire, 1989).

None of the dikes are properly basalts or basanites because plagioclase is always absent. Nepheline is common (olivine nephelinites) and melilite occasional (olivine melilitites). Limburgites represent the most frequent petrographic type characterized by a cryptocrystalline groundmass in which plagioclase is absent and nepheline as well as melilite are not distinguishable. By contrast, plagioclase is always visible in the OVC rocks (strictly basalts and basanites). Those of the RV are much more variable in composition, from basalts to limburgites, olivine nephelinites and olivine melilitites. The presence of biotite is not detected in this unit.

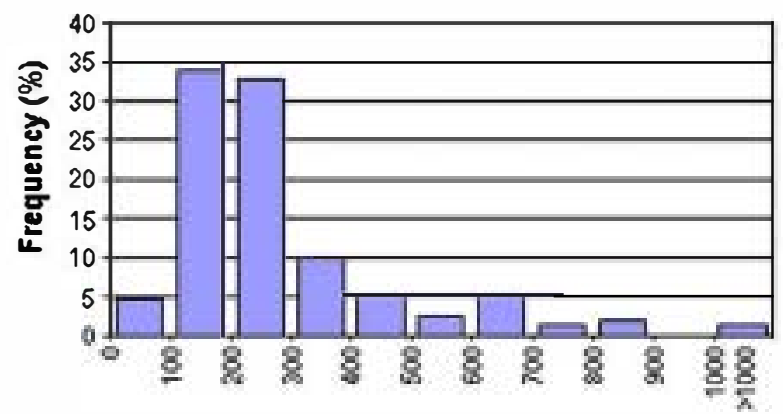

Fig. 6. Variation in length (meters) of the basic dikes (183 measurements).

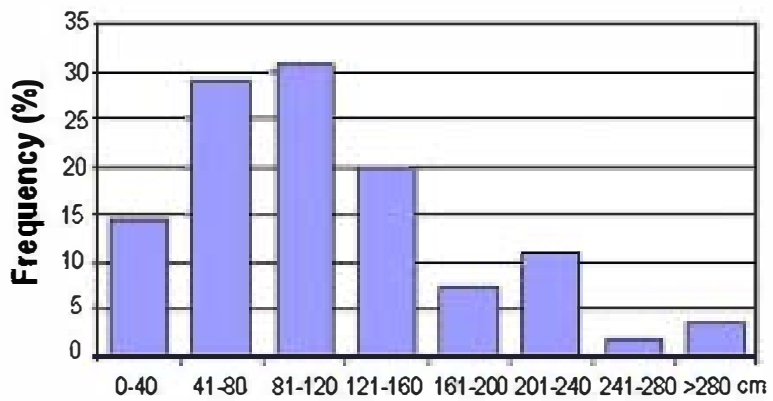

Fig. 7. Variation in thickness of the basic dikes (66 measurements).

Macedo et al. (1995) as well as Dyhr and Holm (2010) present chemical analyses from the OVC and the RV rocks, however many significant trace element are lacking (i.e. most of the REE), on the other hand no data from the dikes are provided. We have analyzed 29 dikes, $18 \mathrm{RV}$ lava flows and, due to the high degree of weathering in this unit, only two OVC lava flows. Major and trace element concentrations were determined by ACГLABS in Ontario (Canada) by X-ray fluorescence spectrometry and inductively coupled plasma-mass spectrometry (ICP-MS).

The three units are all alkaline and mostly ultrabasic $\left(\mathrm{SiO}_{2}<45 \%\right)$ (Table 2). When plotted in the IUGS TAS diagram (Le Maitre, 1989) the BRS dikes are confirmed as foidites and basanites with some more differentiated tephritic members (Fig. 9). The OVC rocks are basanites with a much lesser alkali-content than those from the BRS. The only existent basalts are found in the RV. Among the RV there are also foidites and basanites but they are less alkaline than those from the BRS.

The RV rocks are in general scarcely evolved; MgO content between 17 and 8\% (mean: 11.8\%), Ni between 386 and 224 ppm (mean: $235 \mathrm{ppm}$ ) and $\mathrm{Cr}$ between 865 and $224 \mathrm{ppm}$ (mean: $529 \mathrm{ppm})$. The OVC rocks are also scarcely differentiated: MgO between 15.6 and 7.9\% (mean 12.1\%); Ni between 466 and 92 ppm (mean: $281 \mathrm{ppm}$ ) and $\mathrm{Cr}$ between 1243 and $130 \mathrm{ppm}$ (mean $637 \mathrm{ppm}$ ). By contrast, the dikes are more varied, some of them with a certain degree of differentiation: $\mathrm{MgO}$ between $13.1 \%$ and 4.7\% (mean 8.1\%); Ni between 320 and 40 ppm (mean $144 \mathrm{ppm}$ ) and $\mathrm{Cr}$ between 630 and 20 ppm (mean $255 \mathrm{ppm}$ ).

If a content of $8 \%$ in $\mathrm{MgO}$ is taken as boundary to separate evolved basic rocks from non-evolved ones (i.e.: Klein and Langmuir, 1987; Prytulak and Elliott, 2007), the OCV and the RV rocks would be as a

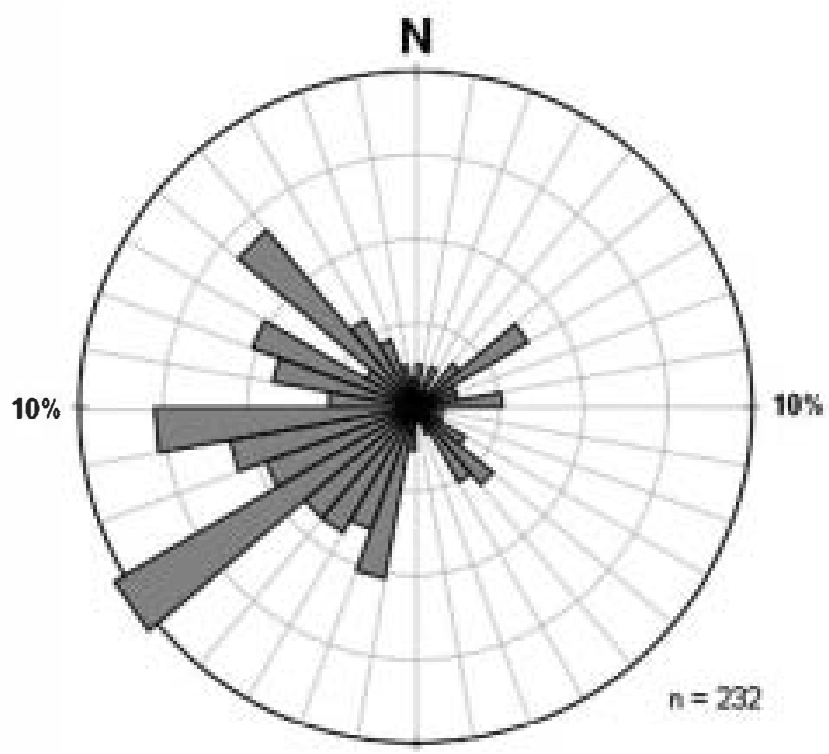

Fig. 8. Rose diagram of Boa Vista basic dike swarm (232 measurements). 
Table 2

Major and trace element concentrations of selected whole rocks of basic units.

\begin{tabular}{|c|c|c|c|c|c|c|c|c|c|c|c|c|c|c|c|c|c|c|}
\hline \multirow[t]{3}{*}{ Sample } & \multirow{3}{*}{$\frac{\frac{\text { OVC }}{\text { B45 }}}{\text { Bas. }}$} & \multicolumn{7}{|l|}{$\mathrm{RV}$} & \multicolumn{5}{|c|}{ BRS $(\mathrm{MgO}>8 \%)$} & \multicolumn{5}{|c|}{ BRS $(\mathrm{MgO}<8 \%)$} \\
\hline & & \multirow{2}{*}{$\frac{\text { B41 }}{\text { Melil. }}$} & \multirow{2}{*}{$\frac{B 43}{\text { Neph. }}$} & \multirow{2}{*}{$\frac{\text { B53 }}{\text { Neph. }}$} & \multirow{2}{*}{$\frac{\mathrm{B} 54}{\mathrm{BSN}}$} & \multirow{2}{*}{$\frac{\mathrm{B} 34}{\mathrm{BSN}}$} & \multirow{2}{*}{$\frac{\mathrm{B} 51}{\mathrm{Bas}}$} & \multirow{2}{*}{ B67 } & \multirow{2}{*}{$\frac{\text { B96 }}{\text { Neph. }}$} & \multirow{2}{*}{$\begin{array}{l}\text { B102 } \\
\text { Foid. }\end{array}$} & \multirow{2}{*}{$\frac{\mathrm{B} 81}{\mathrm{BSN}}$} & \multirow{2}{*}{$\frac{B 68}{\text { Neph. }}$} & \multirow{2}{*}{$\frac{\mathrm{B} 131}{\mathrm{BSN}}$} & & B119 & B132 & B107 & B101 \\
\hline & & & & & & & & & & & & & & Melil. & BSN & BSN & Foid. & Teph \\
\hline $\mathrm{SiO}_{2}$ & 44.53 & 37.34 & 38.13 & 39.86 & 41.16 & 43.26 & 46.13 & 46.86 & 37.51 & 39.95 & 41.04 & 35.25 & 41.14 & 37.20 & 41.27 & 41.06 & 39.62 & 45.36 \\
\hline $\mathrm{Al}_{2} \mathrm{O}_{3}$ & 9.98 & 10.00 & 10.60 & 11.13 & 11.35 & 12.51 & 12.87 & 13.05 & 10.15 & 10.85 & 11.44 & 9.99 & 12.56 & 11.90 & 14.24 & 13.96 & 14.37 & 16.01 \\
\hline $\mathrm{Fe}_{2} \mathrm{O}_{3} \mathrm{t}$ & 14.15 & 12.52 & 13.59 & 13.48 & 13.10 & 13.45 & 12.76 & 11.42 & 13.62 & 13.90 & 13.14 & 15.21 & 12.94 & 14.15 & 11.95 & 11.98 & 13.53 & 9.33 \\
\hline $\mathrm{MnO}$ & 0.19 & 0.24 & 0.23 & 0.19 & 0.19 & 0.20 & 0.20 & 0.17 & 0.19 & 0.20 & 0.19 & 0.22 & 0.18 & 0.18 & 0.18 & 0.16 & 0.22 & 0.18 \\
\hline $\mathrm{MgO}$ & 12.31 & 15.13 & 13.54 & 10.94 & 13.06 & 10.45 & 9.28 & 7.91 & 12.78 & 12.65 & 12.32 & 9.57 & 9.05 & 7.50 & 5.68 & 5.27 & 4.90 & 6.11 \\
\hline $\mathrm{CaO}$ & 10.29 & 15.19 & 14.22 & 12.86 & 11.02 & 11.77 & 11.64 & 11.94 & 14.09 & 12.85 & 11.51 & 15.26 & 12.69 & 14.50 & 11.95 & 13.19 & 10.65 & 8.63 \\
\hline $\mathrm{Na}_{2} \mathrm{O}$ & 1.89 & 2.81 & 2.41 & 3.69 & 2.86 & 2.24 & 2.76 & 2.97 & 2.28 & 1.93 & 2.45 & 2.18 & 3.33 & 2.98 & 3.60 & 3.29 & 4.46 & 4.65 \\
\hline $\mathrm{K}_{2} \mathrm{O}$ & 1.20 & 1.12 & 1.07 & 0.72 & 0.79 & 1.18 & 1.17 & 1.13 & 1.16 & 1.62 & 1.54 & 0.98 & 2.05 & 1.08 & 2.35 & 2.10 & 2.51 & 3.87 \\
\hline $\mathrm{TiO}_{2}$ & 4.34 & 3.32 & 4.22 & 4.27 & 4.14 & 3.43 & 3.36 & 2.68 & 4.76 & 4.38 & 3.61 & 6.12 & 4.66 & 5.75 & 5.16 & 4.92 & 4.78 & 3.24 \\
\hline $\mathrm{P}_{2} \mathrm{O}_{5}$ & 0.62 & 1.38 & 1.01 & 0.81 & 0.63 & 0.59 & 0.54 & 0.50 & 1.05 & 1.01 & 0.69 & 1.60 & 0.98 & 1.58 & 1.47 & 1.16 & 1.89 & 0.65 \\
\hline LOI & 1.23 & 1.47 & 1.31 & 2.53 & 2.17 & 1.15 & 0.07 & 1.47 & 1.78 & 1.47 & 1.09 & 1.75 & 1.17 & 3.45 & 1.97 & 3.16 & 2.45 & 2.39 \\
\hline Total & 100.7 & 100.5 & 100.3 & 100.5 & 100.5 & 100.2 & 100.8 & 100.1 & 99.38 & 100.8 & 99.01 & 98.12 & 100.7 & 100.3 & 99.82 & 100.2 & 99.37 & 100.42 \\
\hline Sc & 25 & 25 & 30 & 25 & 26 & 26 & 26 & 22 & 29 & 27 & 26 & 27 & 25 & 21 & 21 & 18 & 6 & 14 \\
\hline V & 355 & 323 & 349 & 346 & 327 & 331 & 315 & 253 & 389 & 378 & 317 & 461 & 387 & 464 & 395 & 431 & 317 & 282 \\
\hline $\mathrm{Ba}$ & 772 & 1645 & 1451 & 1078 & 859 & 580 & 562 & 592 & 788 & 1274 & 770 & 1234 & 1261 & 1510 & 1974 & 2093 & 1690 & 1326 \\
\hline $\mathrm{Sr}$ & 699 & 1626 & 1041 & 1042 & 828 & 903 & 721 & 662 & 1259 & 1746 & 1069 & 1811 & 1777 & 2270 & 2946 & 2874 & 2605 & 2894 \\
\hline $\mathrm{Y}$ & 28 & 31 & 26 & 26 & 22 & 26 & 25 & 25 & 22 & 23 & 23 & 33 & 25 & 37 & 26 & 29 & 36 & 25 \\
\hline $\mathrm{Zr}$ & 285 & 288 & 233 & 221 & 266 & 227 & 184 & 198 & 219 & 272 & 218 & 237 & 332 & 415 & 274 & 333 & 355 & 429 \\
\hline $\mathrm{Cr}$ & 890 & 530 & 530 & 610 & 610 & 460 & 330 & 320 & 570 & 590 & 630 & 350 & 370 & 130 & 60 & 20 & 60 & 270 \\
\hline Co & 108 & 57 & 61 & 63 & 69 & 54 & 46 & 42 & 71 & 68 & 64 & 55 & 55 & 45 & 39 & 37 & 44 & 36 \\
\hline $\mathrm{Ni}$ & 310 & 300 & 200 & 210 & 360 & 220 & 120 & 120 & 290 & 300 & 320 & 160 & 170 & & 90 & 70 & 70 & 130 \\
\hline $\mathrm{Ga}$ & 20 & 18 & 20 & 21 & 21 & 23 & 20 & 19 & 18 & 20 & 18 & 20 & 24 & 24 & 20 & 22 & 25 & 26 \\
\hline $\mathrm{Rb}$ & 23 & 33 & 23 & 11 & 12 & 29 & 25 & 23 & 28 & 37 & 34 & 21 & 52 & 42 & 39 & 39 & 70 & 91 \\
\hline $\mathrm{Nb}$ & 49 & 98 & 78 & 66 & 68 & 65 & 36 & 41 & 68 & 71 & 60 & 68 & 95 & 110 & 74 & 101 & 147 & 135 \\
\hline $\mathrm{La}$ & 38.9 & 95.7 & 56.6 & 52 & 43.4 & 30 & 31.6 & 28.7 & 45.4 & 49.8 & 35.7 & 57.2 & 52.7 & 71.6 & 49.2 & 66.8 & $\mathbf{9 7 . 5}$ & 53.8 \\
\hline $\mathrm{Ce}$ & 94.1 & 194 & 122 & 113 & 86.3 & 68.9 & 66.8 & 66.7 & 96.3 & 106 & 70.4 & 136 & 108 & 170 & 106 & 134 & 196 & 91.8 \\
\hline $\operatorname{Pr}$ & 12.1 & 22.9 & 15.5 & 14.2 & 10.6 & 8.45 & 9.04 & 8.1 & 12.4 & 13.4 & 9.99 & 18.7 & 13.5 & 21.2 & 14.1 & 17 & 23.9 & 10.2 \\
\hline $\mathrm{Nd}$ & 46.7 & 81.2 & 57.9 & 53.2 & 43.7 & 35 & 34.3 & 31 & 53.5 & 57.9 & 42.6 & 78.1 & 57.8 & 79.7 & 63.1 & 71.9 & 98 & 39.6 \\
\hline $\mathrm{Sm}$ & 10.5 & 15.1 & 11.7 & 10.8 & 9.2 & 8.3 & 7.9 & 7.1 & 11.2 & 11.6 & 9 & 16.7 & 12 & 17.5 & 13.2 & 14.4 & 18.4 & 8 \\
\hline Eu & 3.41 & 4.58 & 3.92 & 3.47 & 2.84 & 2.86 & 2.77 & 2.5 & 3.58 & 3.78 & 2.79 & 5.29 & 3.76 & 5.88 & 4.44 & 4.68 & 5.61 & 2.61 \\
\hline $\mathrm{Gd}$ & 9.3 & 13.1 & 10.8 & 9.9 & 7.6 & 7.6 & 7.3 & 6.8 & 9.1 & 9.6 & 7.6 & 12.9 & 9.8 & 14.6 & 10.6 & 11.8 & 14 & 6.7 \\
\hline $\mathrm{Tb}$ & 1.3 & 1.6 & 1.4 & 1.2 & 1.1 & 1.0 & 1.0 & 1.0 & 1.2 & 1.3 & 1.1 & 1.7 & 1.3 & 2.0 & 1.4 & 1.6 & 1.9 & 1.0 \\
\hline Dy & 7.0 & 7.6 & 6.6 & 6.2 & 5.3 & 5.4 & 5.7 & 5.7 & 5.8 & 6 & 5.5 & 8 & 6.3 & 9.6 & 6.7 & 7.4 & 9.1 & 5 \\
\hline Ho & 1.1 & 1.3 & 1.1 & 1.0 & 0.9 & 0.9 & 1.0 & 1.0 & 1.0 & 1.0 & 1.0 & 1.3 & 1.1 & 1.6 & 1.1 & 1.3 & 1.5 & 0.9 \\
\hline $\mathrm{Er}$ & 2.8 & 3.1 & 2.6 & 2.6 & 2.3 & 2.3 & 2.7 & 2.5 & 2.3 & 2.4 & 2.4 & 3.0 & 2.6 & 3.7 & 2.6 & 3.0 & 3.7 & 2.4 \\
\hline $\mathrm{Tm}$ & 0.36 & 0.38 & 0.32 & 0.32 & 0.28 & 0.3 & 0.34 & 0.33 & 0.27 & 0.29 & 0.3 & 0.33 & 0.32 & 0.42 & 0.31 & 0.36 & 0.45 & 0.34 \\
\hline $\mathrm{Yb}$ & 1.9 & 2.0 & 1.8 & 1.8 & 1.6 & 1.7 & 1.9 & 1.7 & 1.5 & 1.7 & 1.8 & 1.9 & 1.9 & 2.2 & 1.8 & 2.1 & 2.4 & 2.0 \\
\hline Lu & 0.26 & 0.28 & 0.24 & 0.23 & 0.23 & 0.22 & 0.25 & 0.25 & 0.22 & 0.24 & 0.23 & 0.23 & 0.27 & 0.27 & 0.25 & 0.3 & 0.34 & 0.3 \\
\hline $\mathrm{Hf}$ & 8.8 & 6.8 & 6.4 & 5.6 & 6.6 & 5 & 5.1 & 6 & 5.8 & 6.4 & 5.7 & 5.7 & 7.7 & 11.6 & 6.5 & 7.7 & 6.8 & 7.8 \\
\hline $\mathrm{Ta}$ & 3.7 & 5.7 & 5.4 & 5.1 & 4.6 & 3.7 & 2.7 & 3 & 4.4 & 4.5 & 4.5 & 5.4 & 5.8 & 8.7 & 4.4 & 5.9 & 9.9 & 5.3 \\
\hline Th & 3.7 & 8.6 & 5.3 & 4.5 & 4.3 & 2.5 & 2.2 & 3.2 & 3.8 & 4.3 & 3.2 & 6.1 & 4.5 & 7.6 & 4 & 5.9 & 9.2 & 6.2 \\
\hline $\mathrm{U}$ & 0.8 & 2.5 & 1.4 & 1.4 & 1.0 & 1.0 & 0.5 & 0.9 & 0.9 & 1.1 & 0.9 & 1.4 & 1.3 & 2.5 & 1.1 & 1.7 & 2.3 & 2.6 \\
\hline
\end{tabular}




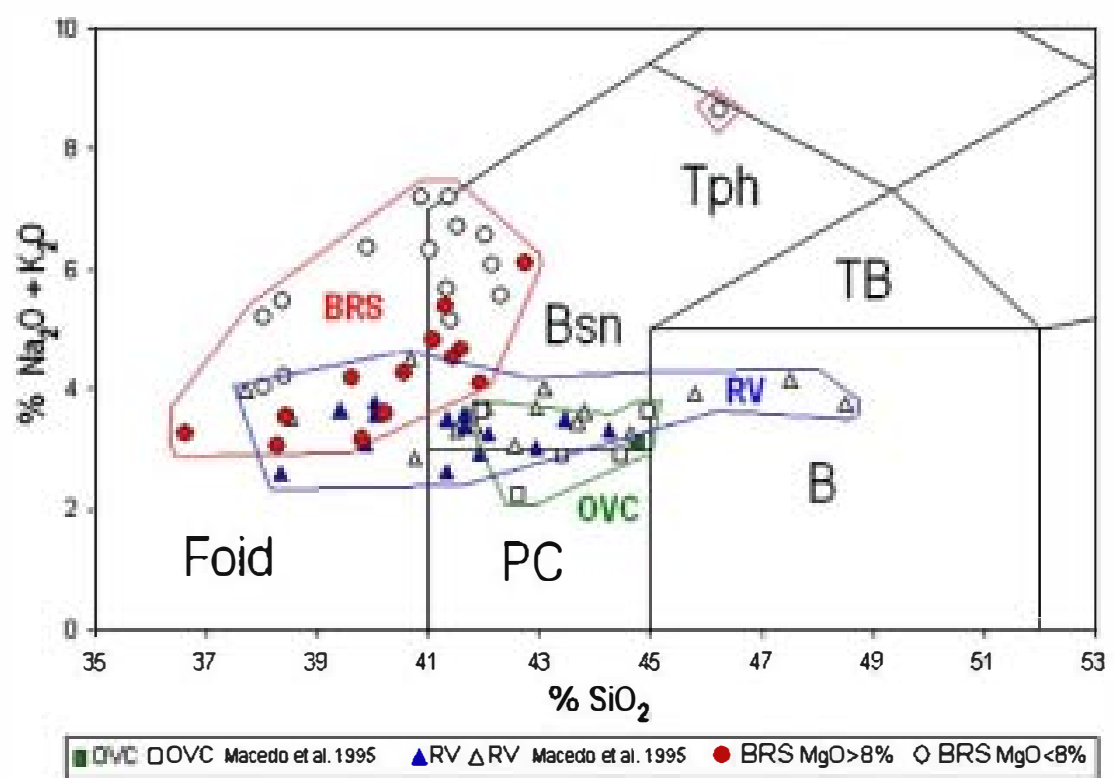

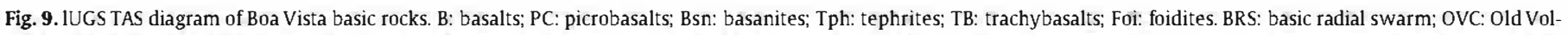
canic Complex; RV: Recent Volcanics.

whole "non-evolved" whereas half of the dikes would be "evolved" and the other half "non-evolved" (Fig. 10).

The most evolved rock samples $(\mathrm{MgO}<8 \%)$ are characterized by higher contents in incompatible elements (Figs. 10 and 11). Among the non-evolved ones, the content in incompatible elements is higher in the BRS than in the OVC and the RV. For instance, the average content in incompatible elements such as $\mathrm{K}_{2} \mathrm{O}, \mathrm{P}_{2} \mathrm{O}_{5}, \mathrm{Rb}$, $\mathrm{La}, \mathrm{Ce}, \mathrm{Nb}$ and Th in samples with $\mathrm{MgO}>8 \%$ from the different units is: $\mathrm{OVC}=1.0 \%$, $0.7 \%, 20 \mathrm{ppm}, 42 \mathrm{ppm}, 100 \mathrm{ppm}, 54 \mathrm{ppm}$ and $3.3 \mathrm{ppm}$ (respectively); $\mathrm{RV}=1.1 \%, \quad 0.7 \%, \quad 24 \mathrm{ppm}, 43 \mathrm{ppm}, 86 \mathrm{ppm}, 55 \mathrm{ppm}$ and $3.8 \mathrm{ppm}$, very similar to the OVC, while BRS $=2.0 \%, 1.4 \%, 49 \mathrm{ppm}$, $67 \mathrm{ppm}, 142 \mathrm{ppm}, 108 \mathrm{ppm}$ and $6 \mathrm{ppm}$. In sum, the content in incompatible elements is between 1.4 and 2.0 times greater in the BRS than in the OVC and the RV.

Primitive mantle-normalized incompatible element patterns are similar to those of other rocks from Cape Verde (i.e. Gerlach et al., 1988; Doucelance et al., 2003; Escrig et al., 2005; Martins et al., 2010). The REE are highly fractionated in all the rock samples especially in the BRS showing average Ia/Yb ratio of 32, 20.5 and 23.1 respectively in the BRS, the OVC and the RV.
Diagrams in Fig. 12 represent a first approach to the main petrogenetic processes controlling the compositional variability of the different basic units. The plotting of two incompatible elements $\mathrm{La}$ and $\mathrm{Ce}$ defining a straight line aligned with the origin indicates that in all the basic units distinguished in Boa Vista partial melting or crystal fractionation were the main petrogenetic processes so that other alternative processes as magma mixing or contamination may be discarded (i.e.: Treuil and Joron, 1975; Allègre and Minster, 1978).

On the other hand, diagrams combining incompatible with other moderately incompatible elements as the $\mathrm{Ce}-\mathrm{Ce} / \mathrm{Y}$ diagram (Fig. 12), allow us to appreciate that most of the geochemical variability observed in the OVC and the RV rocks (straight line with marked slope aligned with the origin) is due to melting processes. By contrast, only the most primary dike rocks ( $\mathrm{MgO}>8 \%$ ) also align with the origin (indicating melting process) whereas those more evolved $(\mathrm{MgO}<8 \%)$ follow a sub-horizontal trend as a result of crystal fractionation.

All the three units (OVC, RV and BRS) are characterized by a high content in $\mathrm{TiO}_{2}$ (4-5\% for $\mathrm{MgO} \approx 10 \%$ ). These $\mathrm{TiO}_{2}$ values are in turn the highest found in Cape Verde, an archipelago already cited for

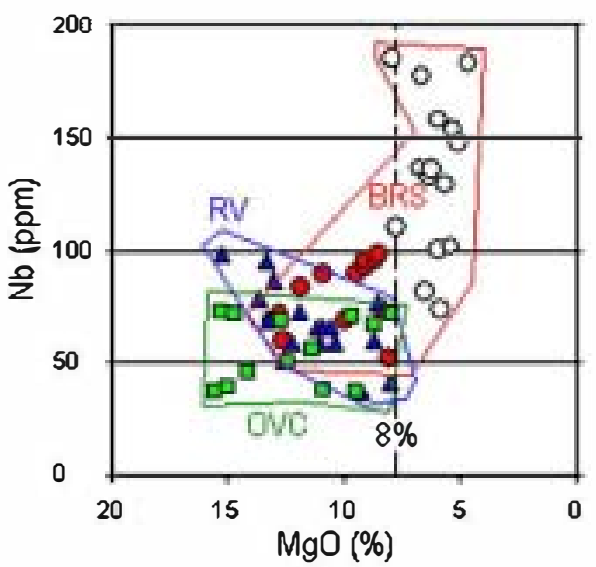

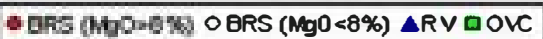

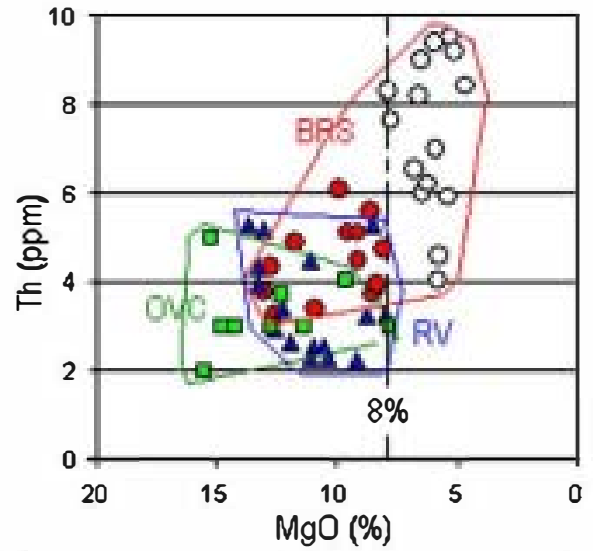

- DRS (MgOO 8\%) OBRS (Mg0<8\%) ARV UOVC

Fig. 10. $\mathrm{MgO}-\mathrm{Nb}$ and $\mathrm{MgO}-\mathrm{Th}$ diagrams. 


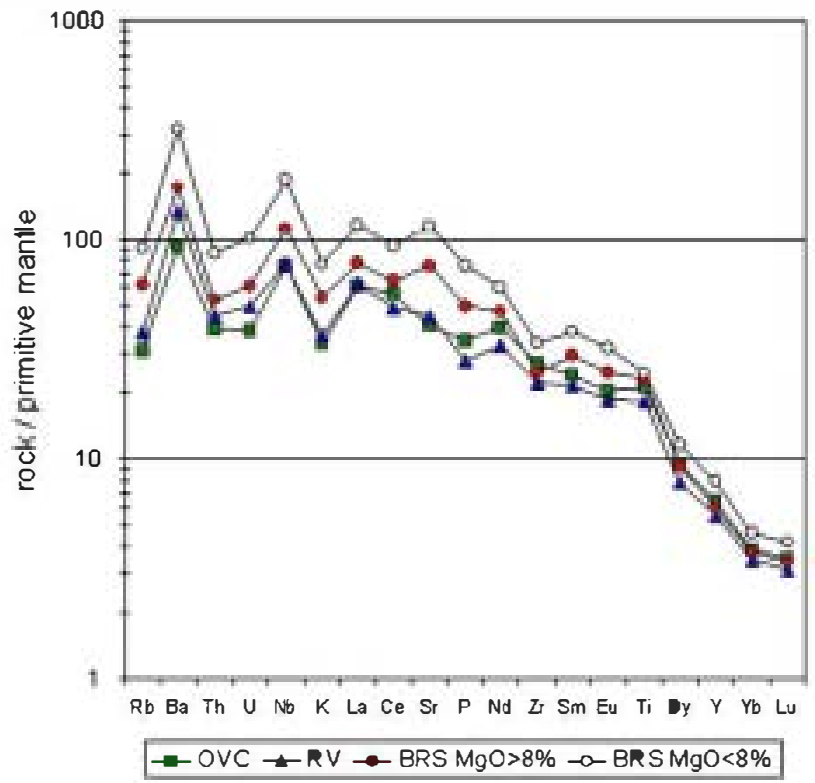

Fig. 11. Multi-element diagram showing concentrations of trace element averages in Boa Vista basic rocks normalized to primitive mantle (Sun and McDonough, 1989).

the highest $\mathrm{TiO}_{2}$-content among the OIB (Prytulak and Elliott, 2007; Barker et al., 2010). Prytulak and Elliott (2007) indicate that so extremely elevated contents cannot be obtained by melting of a fertile peridotitic source and that the participation of pyroxenites/eclogites in the melting is required. Also the high $\mathrm{CaO} / \mathrm{Al}_{2} \mathrm{O}_{3}(>0.86)$ and $\mathrm{Dy} / \mathrm{Yb}(3.3-4)$ ratios denote that the basic rocks as a whole come from a source with garnet (Walter, 1998).

The differences observed in the incompatible element content when rocks with $\mathrm{MgO}>8 \%$ from the three basic units are compared could be due to the fact that the magmas giving rise to the BRS were generated by a considerably lower partial melting degree of a similar mantle source for all of the three units; or/and melting of a mantle source more highly enriched in incompatible elements.

\section{Radiometric age data}

Dyhr and Holm (2010) have reported ${ }^{40} \mathrm{Ar} /{ }^{39} \mathrm{Ar}$ radiometric data from the different units (Table 1). A single rock sample belonging to the OVC basalts gave an age of $16.6 \mathrm{Ma}$; as for the three groups of felsic rocks established by these authors, group 1 was undated, group 2 was dated at $14.3 \mathrm{Ma}$ and $14.22 \mathrm{Ma}$, and group 3 at
13.22 Ma and 12.8 Ma; finally for the RV, younger ages between 8.6 and 4.7 Ma were obtained too.

We have dated 25 rock samples. The material used for dating was represented by "whole-rock" samples of 1 or $2 \mathrm{~g}$, with particle size varying from 0.3 to $1 \mathrm{~mm}$. Phenocrysts were removed from samples of basic rocks (when they were too abundant) using only the rock matrix for analysis. Only alkali feldspar was used for dating the syenites. Samples were dated by the K/Ar method by Mass Spec. Services (USA). Argon was extracted by fusion after degassing at moderate temperature in high vacuum and the ${ }^{38} \mathrm{Ar}$ tracer was added to the analysis using a continuous pipetting system. The analytical errors were calculated according to the method of Dalrymple and Lanphere (1969). Converted ages were calculated using the following constants: ${ }^{40} \mathrm{~K} / \mathrm{K}=1.167 \times 10-2$ atoms $\%, \lambda \varepsilon=0.581 \times 10-10 \mathrm{yr}-1$, $\lambda \boldsymbol{\beta}=4.962 \times 10-10 \mathrm{yr}-1,{ }^{40} \mathrm{Ar} /{ }^{36} \mathrm{Ar}$ atmosphere $=295.5$. All errors are given at the $2 \sigma$ level.

In the alkali feldspar of three syenites from the FSC we have obtained ages of 14.3, 13.0 and $12.8 \mathrm{Ma}$ (Table 3), similar to those given for the phonolites and trachytes from the TPC.

The basic rocks from the different main units established have also been dated (Table 3 and Fig. 13). Two lava flows from the OVC gave ages of $17.5 \mathrm{Ma}$ and $16.4 \mathrm{Ma}$, equivalent to the lava flow dated in 16.6 Ma by Dyhr and Holm (2010), and eight lava flows from the $\mathrm{RV}$, ages obtained were between $6.1 \mathrm{Ma}$ and $4.3 \mathrm{Ma}$, also similar, or in some cases identical, to those previously obtained by the same authors.

Age data from the BRS are not as yet available; we have now dated a dozen rock samples from the radial dike swarm and obtained a group of ages ranging from $14.8 \mathrm{Ma}$ to $11.5 \mathrm{Ma}$. The ages are absolutely different from those of the subaerial basic episodes of the island (OVC and RV), by contrast, they are very similar to those obtained for the TPC phonolites and trachytes (Dyhr and Holm, 2010) and for the FSC syenites (from 14.3 to $12.8 \mathrm{Ma}$, Table 3).

\section{Evolution of the volcanic activity of Boa Vista}

An outstanding feature of Boa Vista is its broadly circular contour-shape. This is a relatively frequent shape for oceanic islands. Even within the Cape Verde archipelago, the much younger island of Fogo has a similar outline (Fig. 14) and also comparable dimensions (25 km in diameter, only about $3 \mathrm{~km}$ less than Boa Vista). In the Canary Islands, La Gomera (22 km) and Gran Canaria (47 km in diameter) share also this characteristic feature. The circular contour-shape of all of them is due to the existence of a single large volcanic complex.

Fogo, of quaternary age (Holm et al., 2006) has a relatively simple volcanic history. By contrast, Gran Canaria (i.e.: Schmincke, 1976,
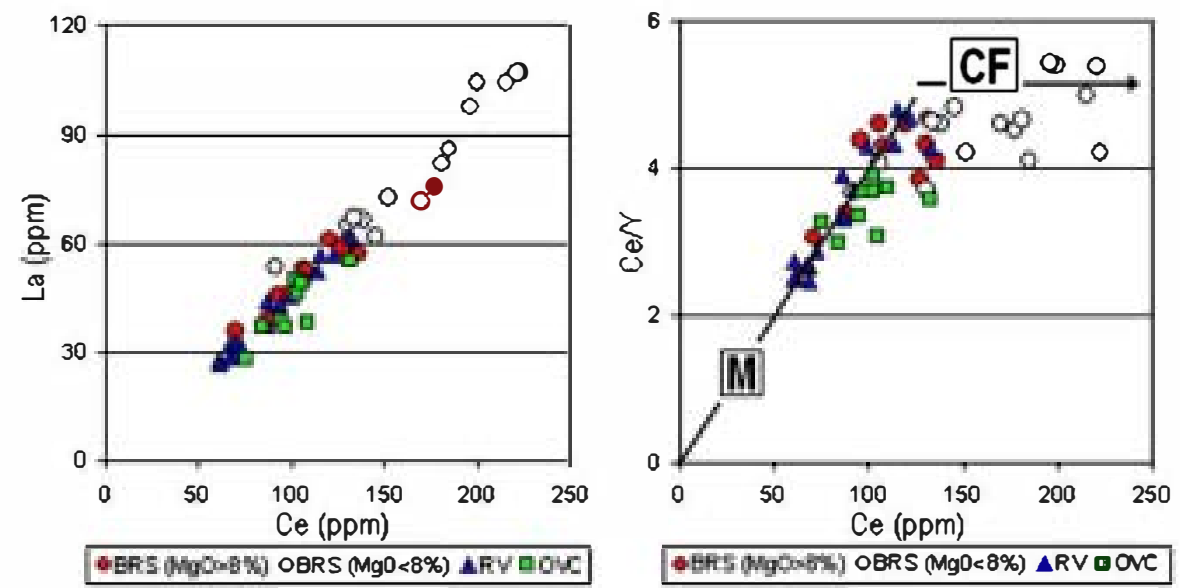

Fig. 12. a) Ce-La diagram. b) Ce-Ce/Y diagram (M: melting; CF: crystal fractionation). 
Table 3

New K/Ar radiometric ages of Boa Vista rocks.

\begin{tabular}{|c|c|c|c|c|c|c|c|c|}
\hline \multirow[t]{2}{*}{ Sample } & \multirow[t]{2}{*}{ Location } & \multirow[t]{2}{*}{ Composition } & \multicolumn{2}{|c|}{ UIM coordinates (27Q) } & \multirow{2}{*}{$\frac{{ }^{\infty} \mathrm{Ar}^{*}}{\left(\mathrm{scc} / \mathrm{gr} \times 10^{-5}\right)}$} & \multirow[t]{2}{*}{$\%{ }^{\circ} \mathrm{Ar}^{*}$} & \multirow[t]{2}{*}{$\% \mathrm{~K}$} & \multirow[t]{2}{*}{ Age (Ma) } \\
\hline & & & $x$ & $\mathrm{Y}$ & & & & \\
\hline \multicolumn{9}{|c|}{ old Volcanic Complex } \\
\hline B-78 & Ribeira da Renca & Basaltic lava flow & 316.215 & 1.784 .881 & 0.056 & 78.0 & 0.84 & $17.5 \pm 0.4$ \\
\hline B-45 & Calhau & Basaltic lava flow & 315.960 & 1.786 .908 & 0.056 & 73.6 & 0.86 & $16.4 \pm 0.4$ \\
\hline \multicolumn{9}{|c|}{ Basic dikes } \\
\hline B-68 & Seladinha & Nephelinitic dike & 306.592 & 1.786 .843 & 0.038 & 61.0 & 0.67 & $14.8 \pm 0.4$ \\
\hline B-81 & SW Morro Amadeirinho & Basanitic dike & 303.342 & 1.781 .801 & 0.092 & 62.8 & 1.65 & $14.4 \pm 0.4$ \\
\hline B -111 & S Morrinho Preto & Basanitic dike & 301.697 & 1.781 .698 & 0.109 & 44.9 & 1.94 & $14.4 \pm 0.4$ \\
\hline B-56 & Ribeira de Rabil & Melilititic dike & 302.195 & 1.778 .594 & 0.049 & 70.7 & 0.90 & $14.2 \pm 0.4$ \\
\hline B-102 & Morrinhos Pretos & Foiditic dike & 301.705 & 1.783 .207 & 0.060 & 47.8 & 1.15 & $13.2 \pm 0.3$ \\
\hline B- 118 & Curral de Roquinho & Nephelinitic dike & 300.916 & 1.778 .043 & 0.059 & 66.6 & 1.16 & $13.2 \pm 0.3$ \\
\hline B-132 & Chao de Morrinhona & Basanitic dike & 306.582 & 1.782 .184 & 0.070 & 57.4 & 1.43 & $12.6 \pm 0.6$ \\
\hline B-96 & Curral de Martinho & Nephelinitic dike & 301.465 & 1.783 .073 & 0.035 & 41.8 & 0.72 & $12.6 \pm 0.4$ \\
\hline $\mathrm{B}-119$ & Curral de Roquinho & Basanitic dike & 301.176 & 1.777 .926 & 0.083 & 50.3 & 1.75 & $12.3 \pm 0.3$ \\
\hline B-107 & Monte Amador & Foiditic dike & 303.489 & 1.783 .817 & 0.090 & 69.3 & 1.93 & $12.0 \pm 0.3$ \\
\hline B-131 & NW Pedrona & Nephelinitic dike & 304.655 & 1.781 .219 & 0.069 & 59.9 & 1.54 & $11.7 \pm 0.3$ \\
\hline B-15 & Monte Amador & Nephelinitic dike & 303.494 & 1.783 .787 & 0.087 & 80.7 & 1.97 & $11.5 \pm 0.3$ \\
\hline \multicolumn{9}{|c|}{ Felsic Subvolcanic Complex } \\
\hline B-58 & Curral de Nelson & Felds. (Ne-syenite) & 302.091 & 1.777 .576 & 0.301 & 57.8 & 5.39 & $14.3 \pm 0.4$ \\
\hline B-9 & Rabil & Felds. (syenite) & 299.079 & 1.782 .177 & 0.322 & 47.4 & 6.18 & $13.0 \pm 0.3$ \\
\hline B-126 & S Belmonte & Felds. (Ne-syenite) & 302.361 & 1.777 .136 & 0.289 & 43.5 & 5.74 & $12.8 \pm 0.4$ \\
\hline \multicolumn{9}{|c|}{ Recent Volcanics } \\
\hline B-77 & Somada Pto. Ferreira & Basaltic lava flow & 319.285 & 1.783 .910 & 0.017 & 44.3 & 0.70 & $6.1 \pm 0.2$ \\
\hline B-26 & Rabil & Nephelinitic lava flow & 298.171 & 1.783 .812 & 0.008 & 5.3 & 0.36 & $5.6 \pm 2.0$ \\
\hline B-54 & Curral de Tabuleiros & Basanitic lava flow & 313.064 & 1.777 .346 & 0.013 & 35.5 & 0.57 & $5.6 \pm 0.2$ \\
\hline B-20 & Cha de Calheta & Basanitic lava flow & 316.711 & 1.778 .207 & 0.010 & 33.8 & 0.49 & $5.2 \pm 0.2$ \\
\hline B-17 & SE Calhau & Basanitic lava flow & 316.590 & 1.787 .783 & 0.021 & 66.2 & 1.22 & $4.5 \pm 0.1$ \\
\hline B-67 & NW Rocha Estancia & Basaltic lava flow & 295.659 & 1.775 .650 & 0.014 & 43.1 & 0.82 & $4.5 \pm 0.1$ \\
\hline B-34 & Playa de Ervalao & Basanitic lava flow & 295.827 & 1.792 .379 & 0.015 & 36.9 & 0.89 & $4.3 \pm 0.2$ \\
\hline B-51 & Morro Negro & Basaltic lava flow & 320.286 & 1.780 .938 & 0.014 & 53.1 & 0.87 & $4.3 \pm 0.1$ \\
\hline
\end{tabular}

1982) and La Gomera (i.e.: Cantagrel et al., 1984; Ancochea et al., 2006, 2008) are a result of longer lasting and more complex activity, resembling that of Boa Vista. Gran Canaria and La Gomera have developed an ample shelf as a result of marine abrasion (Teide Group,
1997; Acosta et al., 2003; Mitchell et al., 2003; Llanes et al., 2009). If we take into account the present size of the islands and their respective insular shelves, Gran Canaria must have reached a diameter of about $65 \mathrm{~km}$, La Gomera $38 \mathrm{~km}$, and Boa Vista $49 \mathrm{~km}$ in the past.

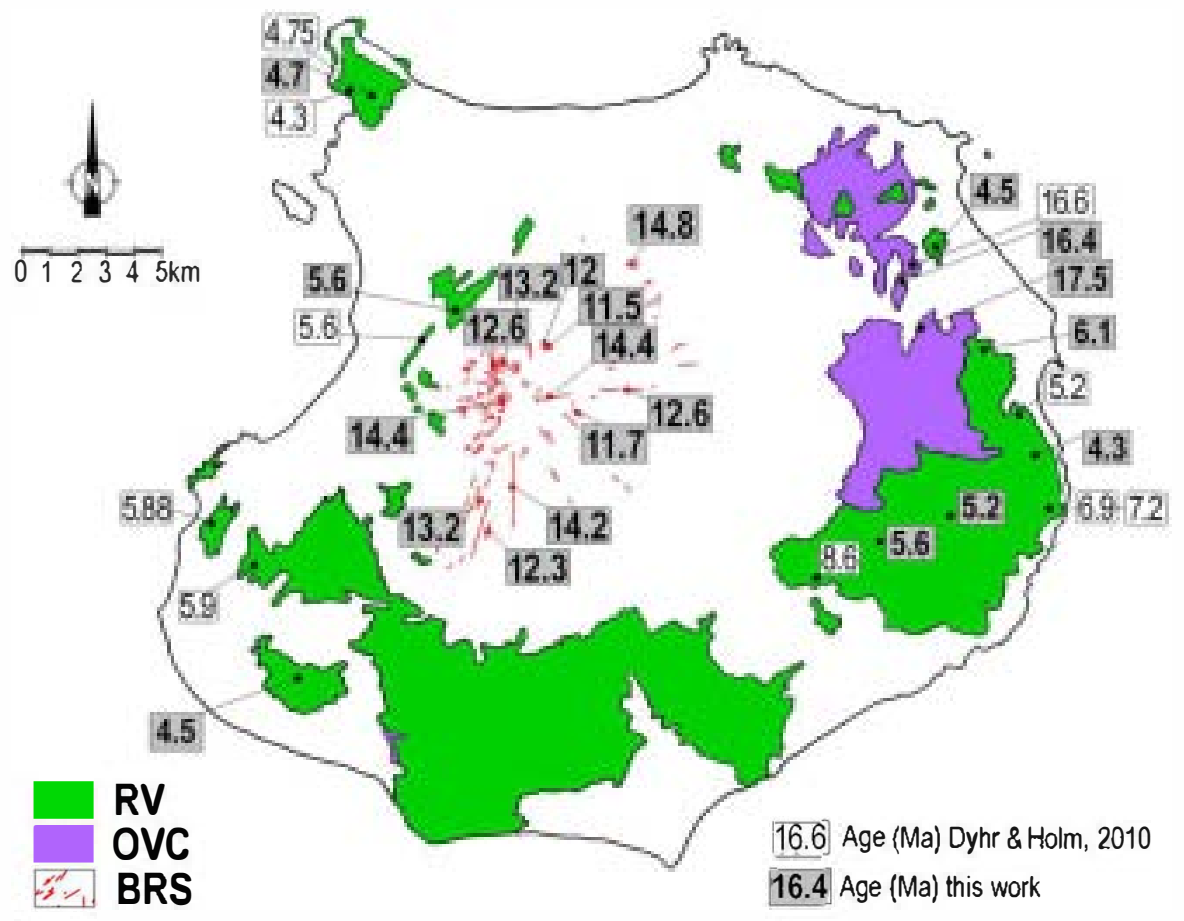

Fig. 13. Radiometric ages from the basic rocks (in Ma). 

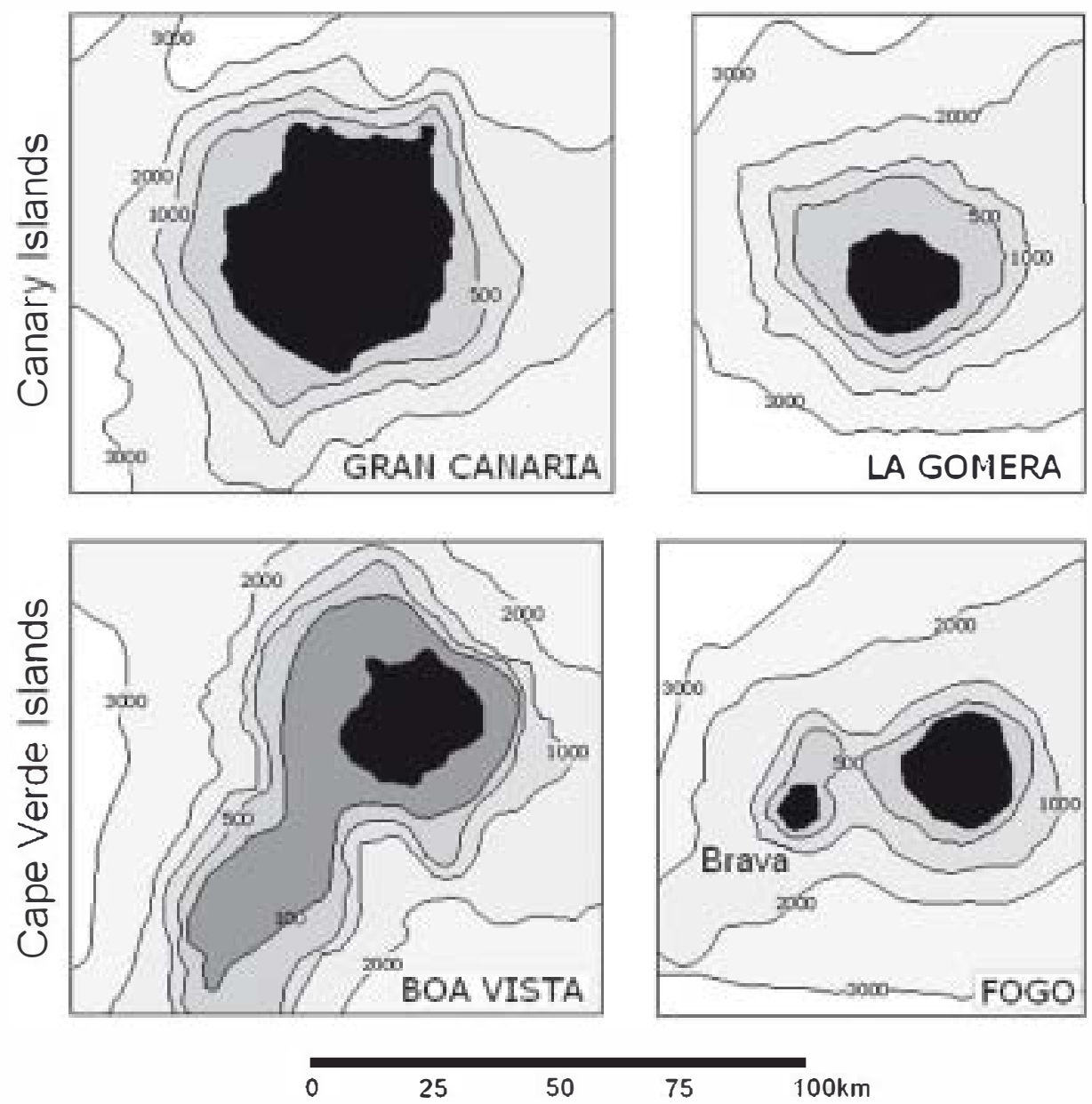

Fig. 14. Simplified bathymetry of contour-shaped Cape Verde and Canary islands.

That is to say, roughly $66 \%$ of the original surface is at present under sea water. A similar percentage (67\%) is deduced for La Gomera, the most similar island to Boa Vista.

Menard (1983) noted that if an island tends to remain at sea level the width of the shelf should increase with age, unless later volcanism occurs resetting such a relationship, and so he established an association between width of the shelf and island age for the Canary Islands. Llanes et al. (2009) make a more accurate estimation by comparing the width of the shelf in every sector of the island contour with the age of the adjacent outcrops.

According to the methods that these authors applied to the Canary Islands, in the case of Cape Verde, a young island such as Fogo should lack platform as it really occurs (Masson et al., 2008) whereas Boa Vista, with a shelf between 6 and $14 \mathrm{~km}$ wide, would have an age between 9 and $20 \mathrm{Ma}$, an idea in agreement with the radiometric age data.

The insular shelf around La Gomera is wider in the northern coast, a fact probably due, as Llanes et al. (2009) affirm, to the trade winds which give rise to a stronger sea swell in that direction and consequently to a more effective wave abrasion. The southward migration of the volcanic activity (Ancochea et al., 2008) could also contribute to enhance the extension of the northern shelf compared to that of the southern coast where younger rocks predominate. In Boa Vista the shelf is more developed in the NW (Fig. 14) in this case likely due to the trade wind effect since, according to the available data, no migration of the activity is observed.

The new geochronological data confirm the existence of three main well defined growth stages in Boa Vista as Dyhr and Holm (2010) have established. The early stage, equivalent to the shield building stage of Hawaii (i.e.: Peterson and Moore, 1987; Langenheim and Clague, 1987;
Moore and Clague, 1992) is represented by the OVC with an age of at least 16-17 Ma (Fig. 15). Its composition (basanites) is rather more alkaline than that of the corresponding Hawaiian stage and similar to that of equivalent stages in the Canary Island and other islands of Cape Verde.

For Serralheiro et al. (1974) and Macedo et al. (1995) their "Complexo eruptivo interno antigo" (Table 1) represented the oldest unit of Boa Vista. Such a unit that no doubt must exist at a deeper erosion level does not crop out in Boa Vista. What they interpreted as the basement for all the later volcanics is, as mentioned above, closely related to the more recent felsic activity. We have not been able to confirm that one of their felsic rock units (the Complexo de Monte Passarao, Table 1) could represent the oldest subaerial volcanic activity.

There are not many definite field and geochronological data to be able to outline an approximate reconstruction of this volcanic complex which, has almost entirely disappeared. At the present time we can only observe some relatively important basic flow piles in the $\mathrm{E}$ and a small isolated outcrop in the $S$ of the island (Fig. 3 and 16a). If, as we suppose, the OVC represents the main volcanic edifice of the island (in the shield stage) it must also have existed formerly in the $W$ and the $N$. As we have already seen, the erosion in these last sectors was likely more intense and consequently could have made most of the OVC disappear and then, younger rocks would have covered the eroded surface.

If we consider that this old edifice extended all over the present island as well as upon its surrounding shelf, the OVC geometrical center would be located northwestwards of the present island center (Fig. 1), a position roughly coincident with that of the center inferred 


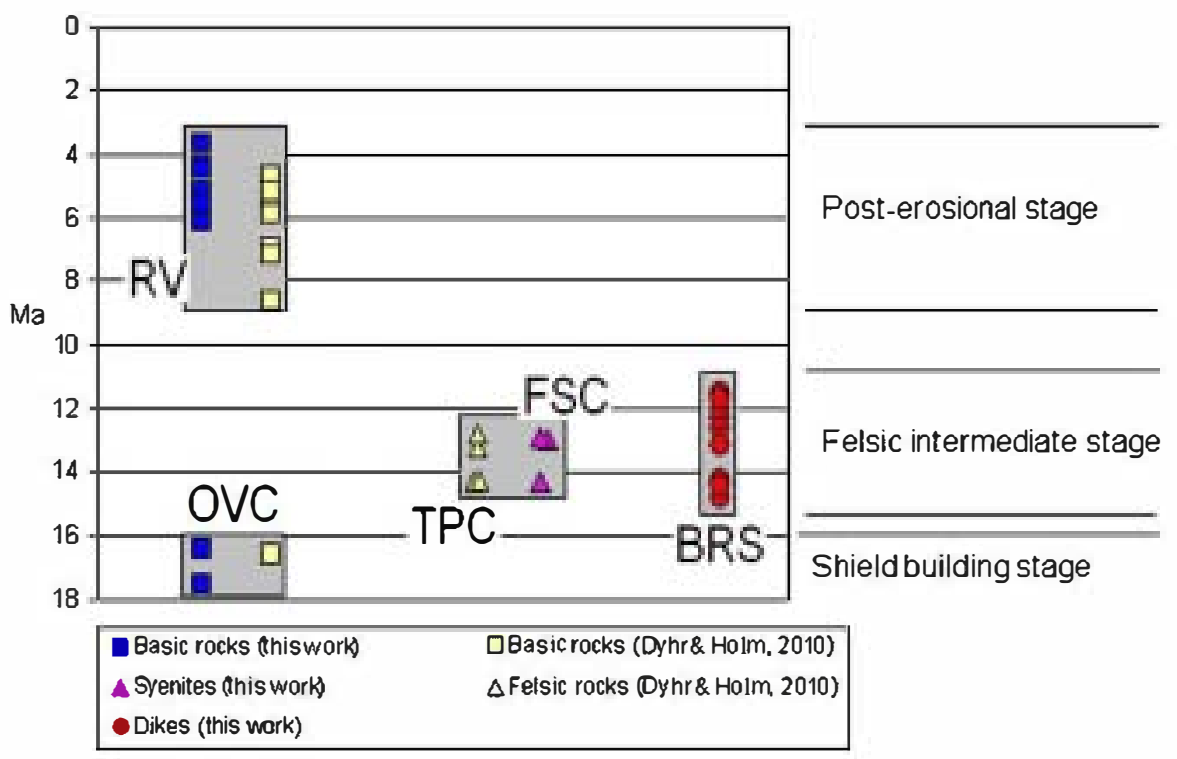

Fig. 15. Age of the different growth stages of Boa Vista.

for the basic dike swarm (Fig. 16a). Admitting this center, a radius between 17 and $20 \mathrm{~km}$ and, a slope of about $4^{\circ}$, typical of the Hawaiian shield stage volcanoes (Mark and Moore, 1987), the height reached by the OVC is estimated between 1200 and $1400 \mathrm{~m}$. For a dipper slope of about $8^{\circ}$ the height would be about $2500 \mathrm{~m}$.

After a possible pause, between 16.4 Ma and $14.8 \mathrm{Ma}$, a second stage in activity that we could properly designated as felsic intermediate stage initiated. This stage has no equivalent in the Hawaiian model of growth but is common in the Canary Islands (Gran Canaria, Tenerife and La Gomera). Except for the BRS basic dikes the rocks in this intermediate stage are felsic (TPC and FSC). The FSC rocks are exposed surrounded by the TPC rocks in the central sector (Fig. 16b). The ages obtained for syenites from the FSC (Table 3) corroborate that these units represent the subvolcanic roots of the TPC.

From the present distribution of felsic rocks it can be inferred that this activity occupied almost totally the island. Taking into account that the most elevated areas of the island always coincide with resistant trachytic and phonolitic (TPC) arcuate and elevated outcrops (i.e.: S. Antonio, Rocha Estancia, Monte Estancia, Caçador, Passarao or Calhau; Fig. 2a), it would be reasonable to expect a similar or even more elevated area $(>300 \mathrm{~m})$ in the central sector where the syenitic roots (FSC) crop out, however, the situation is the opposite, since this is precisely one of the lowermost areas ( $<50-70$ masl).
This morphological situation may points to the existence of an ancient large depression in the central sector of Boa Vista approximately coincident with the area where the FSC rocks are exposed.

The relative abundance of ignimbrites allows us to interpret the depression as a possible ancient collapsed caldera. If so, the high reliefs surrounding the central flat area must represent the remains of the retreated caldera rim and yet the hypothetical caldera would have had a diameter of about $10 \mathrm{~km}$ (Fig. 15b).

An alternative interpretation is that the depression had formed as a result of a slide, a common event that occurred in other islands of Cape Verde, in Fogo, Santo Antao, São Nicolau or São Vicente (Elsworth and Day, 1999; Day et al., 1999; Le Bas et al., 2007; Masson et al., 2008; Ancochea et al., 2010). The mass-wasting event could account for the absence of trachytes and phonolites or other volcanic rock reliefs in the western sector of the island (Fig. 16b). On the other hand, as is usual in some other oceanic islands, the ample embayment existent in the northwestern coast would then be also a track left by this destructive episode. Nevertheless, a further bathymetric study is required to support this hypothesis.

As mentioned above, Dyhr and Holm (2010) dated two of their three compositional groups of felsic rocks, one at 14.3 and $14.2 \mathrm{Ma}$ and the other at 13.2 and $12.8 \mathrm{Ma}$. In spite of the scarce number of rock samples (only two) dated within each of these groups, the

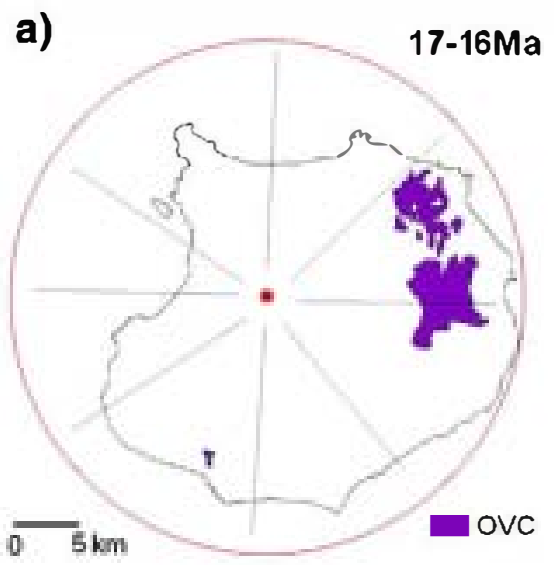

b)

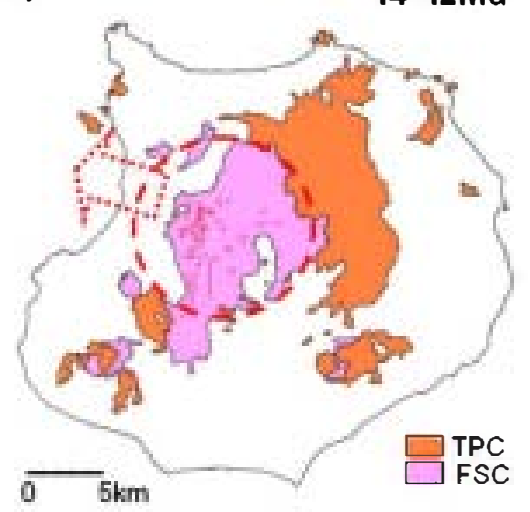

c)

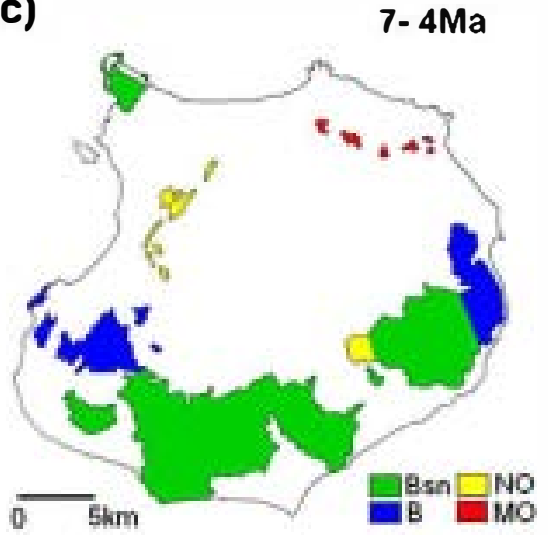

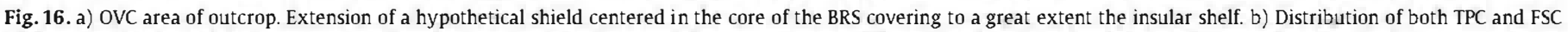

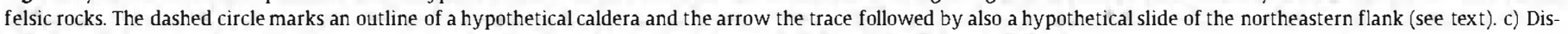
tribution of the areas where the RV outcrop (B: basalts; Bsn: basanites; ON: olivine nephelinites; OM: olivine melilitites). 
results obtained seem to indicate an apparent gap in the felsic activity between 14.2 and $13.2 \mathrm{Ma}$.

Most authors working in Boa Vista have remarked, as one of the most outstanding features of the island, the great abundance of felsic (trachytic and phonolitic) rocks and, at the same time, the absence of intermediate members (absolute lack of rocks with $\mathrm{SiO}_{2}$-content between $47 \%$ and 55\%). Macedo et al. (1995) interpreted the felsic lavas as derived from the basic rocks through crystal fractionation. Dyhr and Holm (2010) also state that two of the three groups of felsic rocks may be evolved by fractionation processes.

The felsic rocks represent $50 \%$ of the areal surface occupied by igneous rocks. No other oceanic island of the Central Atlantic chains reaches so high a percentage. In the Canary Islands, Gran Canaria, and La Gomera also have an important proportion of felsic rocks. Once again we are dealing with circular contoured islands in which, the volcanic activity has remained broadly fixed throughout long periods of time favoring the development of long-lasting large shallow magma chambers where evolved felsic magmas are easily generated.

An important basic radial swarm (BRS) is intruded in the central sector of Boa Vista. The dikes converge at a common area defined by a center situated NW of the island's geographical center (Fig. 4). Since no correspondence is observed between composition and any other of their characteristics, as for example, thickness, length, location or age, all the dikes must belong to a single radial set.

The basic dikes intruding the outcropping old units in the central area of Maio are comparable in both age and composition (basanitic) with the lavic units which cap the island (Furnes and Stillman, 1987). However, this is not the case with the BRS dikes: their geochemical composition as a whole, is different from that of the other basic units (OVC and RV); the dikes are more alkaline, richer in incompatible elements (likely formed by a lower mantle partial melting degree) and include evolved members absent in the other units (Figs. 9 to 12). Apart from the compositional discrepancy there is no other temporal relationship with the OVC and the RV, on the contrary, the age of the dikes (from 14.8 Ma to $12.5 \mathrm{Ma}$ ) is contemporary with that of the TPC and the FSC (Fig. 15). Even an appreciable gap in the age of the dikes (between 14.2 and $13.2 \mathrm{Ma}$, Table 3), coincides with also a short gap observed in the felsic rocks. A more specific geochemical study is needed to analyze the genetic relationships between the basic dikes and the different groups of felsic rocks. On the other hand, the possibility to identify basic subaerial rocks related to the dikes, within either the OVC or the RV exposures in the future, cannot be discarded.

The third stage of activity (equivalent to the Hawaiian post-erosion stage) took place after a relatively prolonged period of quiescence during which the island was drastically eroded and, to a certain extent, invaded by sea water. The period lasted about 3 million years (Fig. 15), from 11.5 Ma (age of the youngest basic dike dated) up to 8.6 Ma (age of the oldest lava flow from the RV dated by Dyhr and Holm, 2010).

The distribution of the RV outcrops occupying a great length on the peripheral zone of the island (Fig. 16c) could give the false idea of a volcanic edifice resembling the previous OVC, however, the volcanic activity in this stage was quite different, now characterized by scattered local eruptive centers from which lava flows spread running over the intensely eroded smooth surfaces. The extension of the RV outcrops is much less important in the north, because a great part of this zone is covered by marine sediments. The thickness developed by the RV lava flow piles varies from only a few lava flows to 100$200 \mathrm{~m}$ thick sequence. This is the case in the easternmost zone where submarine lava flows have yielded ages from 7.2 to $6.9 \mathrm{Ma}$ or, for instance, in the northwestern point where the ages of the lava flows are more recent, between 4.7 and $4.3 \mathrm{Ma}$ according to Dyhr and Holm (2010).

The great variety of compositional types existent in the RV rocks observe a certain order in their arrangement. Most of the rocks are basanites, for example in the northwestern point or in the broad band which extends all along the southern half of the island (Fig. 16c). Basalts are found in the easternmost and the westernmost zones, nefelinites occur associated with basanites in small outcrops situated in a more central position and, finally, melilitites are concentrated in small exposures in the NE.

As in the near island of Maio (Bernard-Griffiths et al., 1975; Grunau et al., 1975; Mitchell et al., 1983; Holm et al., 2008), no evidence of volcanic activity after 4 Ma existed in Boa Vista. By contrast, in Sal also a nearby island there was activity in Pleistocene times (Torres et al., 2002).

\section{Acknowledgments}

The Projects CGL2009-07946 and GI-910469 UCM-CAM supported this work. The authors thank L. Wilson and an anonymous referee for their constructive remarks.

\section{References}

Acosta, J., Uchupi, E., Muñoz, A., Palomo, C., Ballesteros, M., ZEE Working Group, 2003. Geologic evolution of the Canarian islands of Ianzarote, Fuerteventura, Gran Canaria and Ia Gomera and comparison of landslides at these islands with those in Tenerife, La Palma and El Hierro. Marine Geophysical Researches 24, 1-40.

Allègre, C. J., Minster,J.F., 1978. Quantitative models of trace element behaviour in magmatic processes. Earth and Planetary Science Letters 38, 1-25.

Ancochea, E., Huertas, M.J., 2003. Age and composition of the Amanay Seamount, Canary Islands. Marine Geophysical Researches 24, 161-169.

Ancochea, E., Fúster, J.M., Ibarrola, E., Cendrero, A., Coello, J., Hernán, F., Cantagrel, J.M., Jamond, $C, 1990$. Volcanic evolution of the island of Tenerife Canary Islands in the light of new K-Ar data. Journal of Volcanology and Geothermal Research 44, 231-249.

Ancochea, E., Hernán, F., Cendrero, A., Cantagrel, J.M., Fúster, J.M., Ibarrola, E., Coello,J., 1994. Constructive and destructive episodes in the building of a young oceanic island, La Palma, Canary Islands, and genesis of the Caldera de Taburiente. Journal of Volcanology and Geothermal Research 60, 243-262.

Ancochea, E., Brändle, J.L., Cubas, C.R., Hernán, F., Huertas, M.J., 1996. Volcanic complexes in the eastern ridge of the Canary Islands: the Miocene activity of the island of Fuerteventura. Journal of Volcanology and Geothermal Research 70, 183-204.

Ancochea, E., Huertas, M.J., Cantagrel, J.M., Coello, J., Fúster, J.M., Arnaud, N.O., 1999. Evolution of the Cañadas Edifice and its implications on the origin of the Cañadas Caldera Tenerife, Canary Islands. Journal of Volcanology and Geothermal Research 88, 177-199.

Ancochea, E., Brändle, J.L., Huertas, M.J., Cubas, C.R., Hernán, F., 2003. The felsic dikes of Ia Gomera, Canary Islands: identification of cone sheet and radial dike swarms. Journal of Volcanology and Geothermal Research 120, 197-206.

Ancochea, E., Hernán, F., Huertas, M.J., Brändle, J.L., Herrera, R., 2006. A new chronostratigraphy and evolutionary model for La Gomera in the framework of the Canarian archipelago. Journal of Volcanology and Geothermal Research 157, 271-293.

Ancochea, E., Brändle,J.L., Huertas, M.J., Hernán, F., Herrera, R., 2008. Dike-swarms, key to the reconstruction of major volcanic edifices: the basic dikes of La Gomera (Canary Islands). Joumal of Volcanology and Geothermal Research 173, 207-216.

Ancochea, E., Huertas, M.J., Hernán, F., Brändle, J.L., 2010. Volcanic evolution of Säo Vicente, Cape Verde Islands: the Praia Grande landslide. Journal of Volcanology and Geothermal Research 198, 143-157.

Anderson, E.M., 1951. The Dynamics of Faulting and Dyke Formation with Applications to Great Britain. Oliver and Boyd, Edinburgh. (206 pp.).

Barker, A.K., Holm, P.M., Peate, D.W., Baker, J.A., 2010. A 5 million year record of composition variations in mantle sources to magmatism on Santiago, southern Cape Verde archipelago. Contributions to Mineralogy and Petrology 160, 133-154.

Bebiano, J., 1932. A Geologia do Arquipélago de Cabo Verde. Com. Serv. Geol. Portugal, 18 (276 pp.).

Bernard-Griffiths, J., Cantagrel, J.M., Alves, A., Mendes, F., Serralheiro, A., Macedo, J., 1975. Données radiometriques potassium-argon sur quelques formations magmatiques des iles de l'archipel du Cap Vert. Comptes Rendus Académie des Sciences Paris (Ser. D) 280, 2429-2432.

Brändle,J.L., Ancochea, E., Cubas, C.R., Hernán, F., 1991. Análisis de enjambres de diques radiales utilizando un método matemático. Geogaceta 10.

Cantagrel, J.M., Cendrero, A., Fúster, J.M., Ibarrola, E., Jamond, C., 1984. K-Ar chronology of the volcanic eruption in the Canarian Archipelago: Island of Ia Gomera. Bulletin of Volcanology 47, 597-609.

Coello, J., Cantagrel, J.M., Ibarrola, E., Jamond, C. Hernán, F., Fúster, J.M., Ancochea, E., Casquet, C., Díaz de Terán, J.R., Cendrero, A., 1992. Evolution of the eastern volcanic ridge of the Canary Islands based on new K-Ar data. Journal of Volcanology and Geothermal Research 53, 251-274.

Dalrymple, G.B., Lanphere, M.A., 1969. Potassium-Argon Dating: Principles, Techniques and Applications to Geochronology. Freeman, W.H. and Co, San Francisco. (258 pp.). 
Day, S.J., Heleno, S.I.N., Fonseca, J.F., 1999. A past giant lateral collapse and present-day flank instability of Fogo, Cape Verde Islands. Journal of Volcanology and Geothermal Research 94, 191-218

Doucelance, R., Escring, S., Moreira, M., Gariépy, C, Kurz, M.D., 2003. Pb-Sr-He isotope and trace element geochemistry of the Cape Verde archipelago. Geochimica et Cosmochimica Acta 67, 3717-3733.

Dyhr, Ch.T., Holm, P.M., 2010. A volcanological and geochemical investigation of Boa Vista, Cape Verde Islands; ${ }^{4} \mathrm{Ar}$, $\mathrm{Ar}$ geochronology and field constraints. Journal of Volcanology and Geothermal Research 189, 19-32.

Elsworth, D., Day, S.J., 1999. Flank collapse triggered by intrusion: the Canarian and Cape Verde archipelagos. Journal of Volcanology and Geothermal Research 94 , 323-340

Escrig, S., Doucelance, R., Moreira, M., Allègre, C.J., 2005. Os isotope systematics in Fogo Island: evidence for lower continental crust fragments under the Cape Verde southern islands. Chemical Geology 219, 93-113.

Feraud, G., Giannerini, G., Campredon, R., Stillman, CJ., 1985. Geochronology of some Canarian dike swarms: contribution to the volcano-tectonic evolution of the archipelago. Journal of Volcanology and Geothermal Research 25, 29-52.

Figueiredo, M.O., Willians, C.T., Silva, L.C., 1989. Notes on Cape Verde mineralogy. Loparite in Syenitic Rocks from Boa Vista Island: Garcia de Orta, Ser. GeoL, 12 pp. 43-46.

Furnes, H., Stillman, C.J., 1987. The geochemistry and petrology of an alkaline lamprophyre sheet intrusion complex on Maio, Cape Verde Republic. Journal of the Geological Society of Iondon 144, 227-241.

Fúster, J.M., Cendrero, A., Gastesi, P., Ibarrola, E., López Ruiz, J., 1968. Geology and Volcanology of Canary Islands, Fuerteventura. Inst. Lucas Mallada. CSIC, Madrid (243 pp.).

Gerlach, D.C., Cliff, R.A., Davies, G.R., Hodgson, N., 1988. Magma sources of the Cape Verde archipelago: isotopic and trace element constraints. Geochimica et Cosmochimica Acta 52, 2979-2992.

Grunau, H.R., Lehner, P., Cleintaur, M.R., Allenbach, P., Bakker, G., 1975. New radiometric ages and seismic data from Fuerteventura (Canary Islands), Maio (Cape Verde Islands) and Säo Tome (Gulf of Guinea). In: Borradaile, G.J., et aL (Ed.), Progress in Geodynamics. Royal Netherlands Academy of Arts and Sciences, Amsterdam, pp. 90-118.

Hernán, F., 1976. Estudio petrológico y estructural del comple jo traquítico-sienítico de Gran Canaria. Estudios Geológicos 32, 279-324.

Hernán, F., Brändle, J.L., Huertas, M.J., Ancochea, E., 2011. Ios diques básicos del Edificio volcánico principal de la isla de Säo Vicente (Cabo Verde). Geogaceta 40, 95-98.

Holm, P.M., Wilson, J.R., Christensen, B.P., Hansen, L., Hansen, S.L., Hein, K.M Mortensen, A.K., Pedersen, R., Plesner, S., Runge, M.K., 2006. Sampling the Cape Verde mantle plume: evolution of melt composition on Santo Antao, Cape Verde Islands. Journal of Petrology 47, 145-189.

Holm, P.M., Grandvuinet, T., Friis, J., Wilson, J.R., Barker, A.K., Plesner, S., 2008. An ${ }^{40} \mathrm{Ar}-$ ${ }^{39}$ Ar study of the Cape Verde hot spot: Temporal evolution in a semistationary plate environment. Journal of Geophysical Research 113, B-8. http://dx.doi.org/10.1029/ 2007JB005339 (B08201)

Huertas, M.J., Hernán, F., Ancochea, E., Brändle, J.L., 2006. El Edificio Antiguo de la isla de San Vicente Cabo Verde: características del sector occidental Geogaceta 40 5-9

Klein, E.M., Langmuir, C.H., 1987. Global correlations of ocean ridge basalt chemistry with axial depth and crustal thickness. Journal of Geophysical Research 92 8089-8115.

Langenheim, V.A.M., Clague, D.A., 1987. The Hawaiian-Emperor volcanic chain. Part II Stratigraphic framework of volcanic rocks of the Hawaiian Islands. In: Decker R.W., Wright, T.L., Stauffer, P.H. (Eds.), Volcanism in Hawaii: U.S. Geological Survey Professional Paper, 1, pp. 55-84.

Le Bas, T.P., Masson, D.G., Holtom, R.T., Grevemeyer, I., 2007. Slope failures on the flanks of the southern Cape Verde Islands. In: Lykousis, V., Sakellariou, D., Iocat, J. (Eds.) Submarine Mass Movements and Their Consequences. Springer-Verlag, pp. 337-345

Le Maitre, R.W. (Ed.), 1989. A Classification of Igneous Rocks and Glossary of Terms Blackwell Scientific Publications (193 pp.).

Llanes, P., Herrera, R., Gómez, M., Muñoz, A., Acosta, J., Uchupi, E., Smith, D., 2009. Geological evolution of the volcanic island La Gomera, Canary Islands, from analysis of its geomorphology. Marine Geology 264, 123-139.

Macedo, J.R., Matos Alves, C.A., Palacios, T., 1995. Petrología das lavas da ilha de Boavista. Arquipelago de Cabo Verde. Garcia de Orta, Ser. GeoL, 16, pp. 1-18.

Marinoni, L.B, Gudmunsson, A., 2000. Dykes, faults and palaeostress in the Teno and Anaga massifs of Tenerife (Canary Islands). Journal of Volcanology and Geothermal Research 103, 83-103.

Mark, R.K., Moore, J.G., 1987. Slopes of the Hawaiian ridges. In: Decker, R.W., Wright, T.L., Stauffer, P.H. (Eds.), Volcanism in Hawaii: U.S. GeoL Surv., Prof. Pap., 1350 pp. 149-189.
Martins, S., Mata, J., Munhá, J., Mendes, M.H., Maerschalk, C., Caldeira, R., Mattielli, N., 2010. Chemical and mineralogical evidence of the occurrence of mantle metasomatism by carbonate-rich melts in an oceanic environment (Santiago Island, Cape Verde). Mineralogy and Petrology 99, 43-65

Masson, D.G., Le Bas, T.P., Grevemeyer, I., Weinrebe, W., 2008. Flank collapse and largescale landsliding in the Cape Verde Islands, off West Africa. Geochemistry, Geophysics, Geosystems 9, Q07015. http://dx.doi.org/10.1029/2008GC001983.

Matos Alves, C.A., Macedo, J.R., Silva, L.C., Serralheiro, A., Faria, A.F.P., 1979. Estudo geologico, petrologico e vulcanologico da ilha de Santiago (Cape Verde). Garcia de Orta, Ser. GeoL, 3, pp. 47-74.

Menard, H., 1983. Insular erosion, isostasy and subsidence. Science 220 (4600), 913-918.

Mitchell, J., LeBas, M.J., Zielonka, J., Furnes, H., 1983. On dating the magmatism of Maio, Cape Verde Islands. Earth and Planetary Science Letters 64, 61-76.

Mitchell, N.C., Dade, W.B., Masson, D.G., 2003. Erosion of the submarine flanks of the Canary Islands. Journal of Geophysical Research 108 (F1). http://dx.doi.org/ 10.1029/2002JF000003

Moore, J.G., Clague, D.A., 1992. Volcano growth and evolution of the island of Hawaii. Geological Society of America Bulletin 104, 1471-1484.

Peterson, D.W., Moore, R.B., 1987. Geologic history and evolution of geologic concepts, island of Hawaii. In: Decker, R.W., Wright, T.L., Stauffer, P.H. (Eds.), Volcanism in Hawaii: U.S. GeoL Surv, Prof. Pap., 1, pp. 149-189.

Pollitz, F.F., 1991. Two-stage model of African absolute motion during the last 30 million years. Tectonophysics 194, 91-106.

Prytulak, J., Elliott, T., 2007. $\mathrm{TiO}_{2}$ enrichment in ocean island basalts. Earth and Planetary Science Letters 263, 388-403.

Ramalho, R.S., Helf frich, G., Cosca, M., Vance, D., Hoffmann, D., Schmidt, D.N., 2010. Vertical movements of ocean island volcanoes: insights from a stationary plate environment. Marine Geology 275, 84-95

Richey, J.E., 1939. The dykes of Scotland. Transactions of the Edinburgh Geological Society $13,393-435$

Schirnick, C., Bogaard, P.D., Schmincke, H.U., 1999. Cone sheet formation and intrusive growth of an oceanic island. The Miocene Tejeda complex on Gran Canaria (Canary Island). Geology 27, 207-210.

Schmincke, H.U., 1967. Cone sheet swarm, resurgence of Tejeda Caldera, and the early geologic history of Gran Canaria. Bulletin of Volcanology 31, 153-162.

Schmincke, H.-U., 1976. Geology of the Canary Islands. In: Kunkel, G. (Ed.), Biogeography and Ecology of the Canary Islands. Junk, The Hague, pp. 67-184.

Schmincke, H.-U., 1982. Volcanic and chemical evolution of the Canary Islands. In: Von Rad, U., Hinz, K., Sarnthein, M., Seibold, E. (Eds.), Geology of the Northwest African Continental Margin. Springer-Verlag, pp. 273-306.

Serralheiro, A., Matos Alves, C.A., Macedo, J.R., Silva, L.C., 1974. Note préliminaire sur la géologie de líle de Boa Vista Cap-Vert. Garcia de Orta, Ser. GeoL, 1, pp. 53-60.

Silva, L.C., Figueiredo, M.O., Williams, C.T., 1989. Notes on Cape Verde mineralogy. Zirconium silicate in syenitic rocks from Boa Vista Island. Garcia de Orta, Ser.GeoL, 12 pp. $37-42$.

Staudigel, H., Feraud, G., Giannerini, G., 1986. The history of intrusive activity on the island of La Palma (Canary Islands). Journal of Volcanology and Geothermal Research 27, 299-322.

Stillman, C.J., 1987. A Canary Islands dyke swarm: implications for the formation of oceanic islands by extensional fissural volcanism. In: Halls, H.C., Fahrig, W.J (Eds.), Mafic Dyke Swarms: GeoL Assoc. Can. Spec. Pap., 34, pp. 243-255

Stillman, C.J., Fúster, J.M., Bennell-Baker, M.J., Muñoz, M., Smewing, J.D., Sagredo, J. 1975. Basal complex of Fuerteventura (Canary Islands) is an oceanic intrusive complex with rift-system affinities. Nature 257, 469-471.

Sun, S.S., McDonough, W.F., 1989. Chemical and isotopic systematic of oceanic basalts: implications for mantle composition and processes. In: Saunders, A.D., Norry, M.J. (Eds.), Magmatism in the Ocean Basins: GeoL Soc. Sp. PubL, 42, pp. 313-345.

Teide Group: Palomo, C., Acosta, J., Sanz,J.L., Herranz, P., Muñoz, A., Uchupi, E., Escartin, 1997. Morphometric interpretation of the northwest and southeast slopes of Tenerife, Canary Islands. Journal of Geophysical Research 102, 20325-20342.

Torres, P.C., Silva, L.C., Serralheiro, A., Tassinari, C., Munha, J., 2002. Enquadramento geocronologico pelo metodo $\mathrm{K} / \mathrm{Ar}$ das principais sequencias vulcano-estratigraficas da Ilha do Sal; Cabo Verde. Garcia de Orta. Ser. Geol 18, 9-13.

Treuil, M., Joron, J.L., 1975. Utilisations des elements hygromagmatophiles pour la sim plification de la modelisation quantitative des processus magmatiques. Exemples de l'Afar et de la dorsale mediatlantique: Soc. Ital Mineral. Petrol., 31, pp. 125-174

Walter, M.J., 1998. Melting of garnet peridotite and the origin of komatiite and depleted lithosphere. Journal of Petrology 39, 29-60.

Walter, T.R., Schmincke, H.U., 2002. Rifting, recurrent landsliding and Miocene structural reorganization on NW-Tenerife Canary Islands. International Journal of Earth Sciences Geologische Rundschaı 91, 615-628. 